\title{
Exile: Banishment as a Punitive and Coercive Measure
}

\begin{abstract}
The first of two main chapters, this analyses the exclusion of offenders and what this can tell us about the values of late medieval Kampen society concerning morally acceptable behaviour. This chapter firstly focuses on typologies and quantitative aspects of banishment, such as the number of exiles of various categories. It then discusses the question whether the punishment was mainly used as a punitive or coercive measure, before moving onto the distance and duration of banishments. An important part of this chapter is the discussion of aspects of gender and morality, and of social status, as this provides insights into the values of the town community. Symbolism and ceremony are discussed to establish their role in the application of authority by the magistrates. The final section analyses whether an army of exiles existed beyond Kampen's walls.
\end{abstract}

Keywords Crime $\bullet$ Morality $\bullet$ Gender $\bullet$ Social status $\bullet$ Ritual

It is clear that the Kampen magistrates utilised different punishments and related measures in the later middle ages to administer justice over its inhabitants and over visitors, and to communicate a range of messages about the maintenance of law and order. Within this context of punishment, banishment was reasonably common. In this chapter, various aspects of banishment in Kampen will be discussed to gain a clearer picture of the

(C) The Author(s) 2022

E. Frankot, Banishment in the Late Medieval Eastern Netherlands, https://doi.org/10.1007/978-3-030-88867-1_4 
types of banishments, how often people were banished and for what crimes, and whether and how gender and social class played a role in the punishment. In addition, this chapter discusses whether banishment was used mainly as a punitive or a coercive measure, and to what extent ritual and ceremony played a role in banishment practices. Finally, it analyses whether the use of banishment resulted in an army of exiles outside of Kampen's walls.

\section{Typology, Numbers And Crimes}

Authors analysing banishment have differentiated between various functions and types of banishment. Carl Hoffmann, for example, has suggested six different functions, though he states that it is not always possible to differentiate between them: banishment as (part of a) primary punishment; as a coercive measure; as a policing measure to remove unwanted people and groups; as a punishment on the basis of suspicions; as a result of not appearing in court; and as a merciful replacement for capital punishment. ${ }^{1}$ Some of these functions are also recognisable in Kampen, though it is often difficult to differentiate between banishment as a coercive measure and as a result of not appearing in court. This is because the sequence of events is not always clear from the evidence and because the functions might overlap. There is no specific mention in Kampen of banishment being used as a merciful replacement for capital punishment, but banishments were imposed for small thefts when theft could also be punished by death.

Hoffmann also lists six different types of banishment: banishment without further specification; temporary banishment; life-long banishment; banishment with corporal punishment; banishment as a coercive measure; banishment with a fine. ${ }^{2}$ Apart from the final type, these are also all recognisable in Kampen. In addition, it is possible to differentiate between different distances that exiles had to keep from town. However, such distances were always combined with one of the already mentioned types and it is not always possible to recognise a systematic application of different distances. ${ }^{3}$ Distances and duration will be discussed further below. First, the focus will be on the number of banishments as primary punishments and those imposed as a coercive measure and/or a result of flight.

\footnotetext{
${ }^{1}$ Hoffmann, 'Der Stadtverweis', 198.

${ }^{2}$ Ibid., 202.

${ }^{3}$ See also ibid., 204.
} 
Table 4.1 Number of people banished according to the main registers

\begin{tabular}{lllll}
\hline Register & Period & Total exiles & Male & Female \\
\hline Banishment reg. & $1447-1500$ & $1267(+18)^{\mathrm{a}}$ & $1180(+15)$ & $87(+3)$ \\
Oerveden reg. & $1447-1500$ & 108 & 83 & 25 \\
Digestum Vetus+Liber Causarum & $1454-1500$ & $53(16+37)$ & $20(10+10)$ & $33(6+27)$ \\
Total & & $1428(+18)$ & $1279(+15)$ & $149(+3)$ \\
\hline
\end{tabular}

${ }^{a}$ For the 18 between brackets, see note 4

The first question to address with regard to numbers is how many people were cast out of Kampen each year and how many of these were exiled as the main punishment. Between 1447 and 1500, 1446 people were recorded in the banishment and oerveden registers, the Digestum Vetus and the Liber Causarum as having been banished (see Table 4.1). There is a small number of cases which appears in more than one register, but this number is negligible. Many of those banished for failure to pay their fine can be found in the lists of fines recorded in the Liber Testium (only covering the years 1483-93). There, on occasion, the note 'uutgt' (short for 'uutgelecht': banished) was added to indicate that someone had been exiled after the penalty had been meted out. Most of these latter entries were subsequently copied (the majority in an expanded version) into the register of banishments. As such, these do not appear separately in the table. ${ }^{4}$ On average $26-27$ people were exiled annually according to the records, keeping in mind that only the banishment and oath registers cover the first seven years of this period. There are few comparable numbers available from elsewhere in Europe. In fourteenth-century Valenciennes, with a population estimated to have been anywhere between 7500 and 30,000 inhabitants, about 53 people were banished per annum. ${ }^{5}$ In the late twelfth and thirteenth centuries, 3-3.5 people were ousted annually from Saint-Quentin, a town which at that time was likely not much smaller than Kampen in the fifteenth century. ${ }^{6}$ These numbers vary

\footnotetext{
${ }^{4}$ Eighteen people in the Liber Testium cannot be linked with certainty to exiles in the banishment register-a few of the offenders may be listed under an alias. For example, Lysbeth Maes, who is named with Henric Kaye (LT, f. 76v (1486)), may be the same as Betthe Bleeckster, named with Wessel Kaye in the same year (Reg, p. 134 (1486)), a bleeckster being a woman who bleaches cloth.

${ }^{5}$ Huart, 'Maintenir la paix', 12.

${ }^{6} \mathrm{Hamel}$, 'Bannis et bannissement', 130 .
} 
significantly, but without clear estimates of population numbers, it is difficult to make any useful comparisons.

Of the Kampen exiles, only a minority was sentenced to banishment in the first instance. The rest was charged with fineable offences, but they either fled the town before being caught and were sentenced to banishment in absentia (stating the fine as the primary punishment), or they were unable to pay the fine and as a result were declared banished from the town community. These two groups were recorded in the banishment register and together make up 88.7 per cent of the total. There are also at least 12 individuals in the oerveden register who were banished for the non-payment of fines, in addition to 15 who arranged to pay their fine following their oervede oath. The latter were allowed to remain in Kampen. It may be the case that offenders were taken into custody when they were caught following fineable offences, especially if they could not find people to stand surety for them. They then had to swear an oervede oath on their release, before they either paid their fine (or arranged for payment in instalments) or were banished for not paying it. The twelve individuals who were banished following the non-payment of their fine were partly evicted outright, whereas others were offered a possibility to return if they paid their fine. For example, Geert Hugensz, a fish merchant from Utrecht, had wounded a clerk and could not pay, so he was told not to return to Kampen ('sal niet weder in Campen komen'). ${ }^{7}$ Herman van Oldensiel was flogged and then banished for wounding the lady Stakenberg at night. The fine of $200 \mathrm{lb}$. is named, but he was told to stay at a distance of one mile from the town. ${ }^{8}$ Arnt Geertsz too was flogged, before being banished at a distance of two miles until he could pay his fines adding up to $220 \mathrm{lb}$. $(100+80+40 \mathrm{lb}$. $) .{ }^{9}$ The variation in the sentencing in these three cases suggests that the magistrates differentiated between offenders and that banishment did not always function as a coercive measure following an unpaid fine. In some cases, banishment rather became a replacement for the fine. As a result of lacking additional information, it is difficult to say whether the difference in treatment was based on the social status of the culprit (e.g. whether they were an inhabitant or not) or on the status of the victim. The question of punishment or coercion will be discussed further below.

\footnotetext{
${ }^{7}$ Reg, p. 23 (1491).

${ }^{8}$ Reg, p. 8 (1466).

${ }^{9}$ Reg, p. 8 (1464).
} 
When analysing the overall numbers recorded in the same four registers, then, banishment as the primary punishment is not as common as the banishment register might at first glance suggest. Less than one in eight exiles (about three per annum) were cast out of the town as a punishment for a crime committed which was punishable by banishment. The remainder had originally been fined or they had fled from justice. That banishment after failing to pay a fine was not as prevalent everywhere is shown by the example of fourteenth-century Valenciennes, where only a small percentage (less than 4 per cent) was cast out for this reason. ${ }^{10}$ Numbers for other towns in the Netherlands are lacking.

In Kampen, the relevant fines had mostly been meted out for violent offences. Between 1475 and 1500 , for example, 501 crimes were recorded in the banishment register. In 194 more cases just a fine was recorded, but not the associated crime. Of the 501 crimes that were recorded, 285 had consisted of a wounding and another 130 were for other violent offences, such as stabbing, beating, kicking, biting and fighting. The fines for these ranged from 20 to $100 \mathrm{lb}$. (and double that if committed at night). ${ }^{11}$ There were also 12 cases of manslaughter. Manslaughter was actually punishable by banishment, at least until a reconciliation took place. ${ }^{12}$ In 1426 a fine for manslaughter was set at $400 \mathrm{lb}$. and such a fine is recorded on occasion. ${ }^{13}$ It is likely that in most cases offenders would have fled the scene of the crime after a killing so they could arrange a reconciliation through mediation by others from a safe distance. Altogether 427 out of 501 known crimes in the banishment register between 1475 and 1500 were violent ( 85.2 per cent).

There would have been few people in Kampen who would have been able to easily pay the large fines set for violent crimes. For example, the highest paid official on the council's payroll, the town's senior secretary, was paid $260 \mathrm{lb}$. annually. ${ }^{14}$ The guards were paid between 60 and $112 \mathrm{lb}$. per annum. The average amount that debtors were paying back in instalments per year (see Chap. 5 ) was between 30 and $44 \mathrm{lb}$. Considering rentals of town properties, the largest amount was due for the bridge, namely

\footnotetext{
${ }^{10}$ In total 97 out of 2600 were banished for unpaid fines. Huart, 'Maintenir la paix', 11.

${ }^{11}$ Originally the punishment for a wounding at night was the loss of a hand (GB, f. $39 \mathrm{r}$ (1334)), but in practice a fine of $200 \mathrm{lb}$. was meted out.

${ }^{12} \mathrm{BvR}$, f. 22v (1385).

${ }^{13}$ GB, f. 48r (1426). For example, Reg, p. 140 (1490).

${ }^{14}$ In the original source, these payments are stated in hern $\mathrm{lb}$.: 65 hern $\mathrm{lb}$. for the senior secretary, between $12 \frac{1}{2}$ and 28 hern lb. for the guards. On currency, see Chap. 3, n. 5 .
} 
$2000 \mathrm{lb}$. in 1490, which was paid in ten instalments. Most other rents were below $400 \mathrm{lb}$., and most were paid in a number of terms and often with the help of others. ${ }^{15}$ It can be assumed that these rentals were only taken up by the more affluent of Kampen's citizens, but even they rarely paid more than $120 \mathrm{lb}$. at a time for them. As such, only the elite would most likely have been able to pay a high fine immediately. ${ }^{16}$ Possibly the magistrates had taken the likelihood that many violent offenders would flee the town or would be unable to pay a fine (and as a result be banished) into account when they set their fines, perhaps considering this as a relatively straightforward way of ridding the town of undesirables. I will return to this below.

Of course, we should ask ourselves whether violent behaviour in itself was considered to be undesirable in late medieval society. It is wellestablished that (violent) conflict was common at this time. ${ }^{17}$ In addition, confrontations have been shown to have developed according to a set sequence of acts, from verbal exchanges to potentially drawing blood and killing an opponent. Such 'rituals of confrontation' have been recognised in different geographical contexts, such as England, France, Germany and Italy. ${ }^{18}$ The confrontations often followed a set formula, starting with verbal abuse, followed by gestures and eventually leading to blows. At any stage in these confrontations opponents could retreat, either of their own volition or because they had been convinced by bystanders. In the final stages, this violence could lead to injury or even death, but it has been argued that, because of their ritualised nature, most confrontations ended without any bloodshed. Charles Pythian-Adams, for example, has shown that striking with the flat of the sword, rather than the edge, was common. ${ }^{19}$ Similarly, Trevor Dean has pointed to the use of sword blades. ${ }^{20}$ As such, the intention was to bruise or hurt an opponent, but not to draw blood, maim or kill. A wide variety of 'weapons' could potentially be used:

${ }^{15} \mathrm{SR}$, ff. $172 \mathrm{v}-175 \mathrm{v}$.

${ }^{16}$ Concerning high fines and the inability of offenders to pay them, see also Næss and Österberg, 'Sanctions, agreements, sufferings', 147.

${ }^{17}$ See, for example, Zaremska, Les bannis au Moyen Âge, 152; Hoffmann, 'Der Stadtverweis', 214.

${ }^{18}$ Pythian-Adams, 'Rituals of personal confrontation'; Gauvard, 'De grace especial', 707-45; Schuster, Stadt vor Gericht, 86-90; Dean, Crime and Justice in Late Medieval Italy, Ch. 9.

${ }^{19}$ Pythian-Adams, 'Rituals of personal confrontation', 83.

${ }^{20}$ Dean, Crime and Justice in Late Medieval Italy, 169. 
jugs were common in Kampen, but anything that came to hand could be used to cast a blow. ${ }^{21}$ This suggests that many confrontations were not pre-meditated (Peter Arnade and Walter Prevenier call them 'unplanned'), ${ }^{22}$ but occurred in social situations, such as in various drinking establishments. The use of any kind of weapon incurred the same fine in Kampen: for example, the pouring of milk at someone ('om dat sie na lange Johan gegoten heft mit melke' $)^{23}$ resulted in the same $40 \mathrm{lb}$. fine as stabbing at someone with a knife without wounding them. At the same time a blow with a fist incurred a fine of 2 or $10 \mathrm{lb}$. It may be that pouring milk as a gesture in an escalating confrontation had the same symbolic meaning as pulling out a knife. In both cases an item was thrust towards someone to make a certain statement. The item could potentially be used to cause more damage, both physically and to one's reputation, though it is questionable that pouring milk would cause any physical damage.

It has been argued that most confrontations did not go beyond verbal abuse or the use of fists, and indeed, in Kampen in 1490, 27 people incurred a fine for using offensive language and 17 had used their fists. ${ }^{24}$ However, there were also 16 individuals charged with wounding someone and 1 with manslaughter. Virtually all of these individuals ended up being banished for failing to pay their fine. It appears, then, that, if ritualistic confrontations were also part of legal culture in Kampen (which they may well have been judging by the strict categorisation of violence as reflected in fines), these did not prevent a relatively high proportion of woundings. They also did not avert a higher number of deaths than, for example, in Konstanz which had a similar population size. In Cracow in the late fourteenth century, the number of deaths was much higher again. ${ }^{25}$ This variation suggests that we need to be careful issuing universal truths about ritualistic violence and the prevention of serious injury in late medieval Europe.

${ }^{21}$ See also ibid.; Schuster, Stadt vor Gericht, 90.

${ }^{22}$ Concerning unplanned violence and differences between young men and heads of households, see Arnade and Prevenier, Honor, Vengeance, and Social Trouble, 82-9.

${ }^{23}$ Reg, p. 84 (1451).

${ }^{24}$ See, for example, Schuster, Stadt vor Gericht, 87; Dean, Crime and Justice in Late Medieval Italy, 169.

${ }^{25}$ In Konstanz, there were 9 deaths between 1430 and 1460, when there were 16 between 1480 and 1499 in Kampen. In Cracow, there were at least 62 in 1380-84, on a population of 10,000. Schuster, Stadt vor Gericht, 89; Zaremska, Les bannis au Moyen Age, 152. 
The setting of high fines for various acts of violence may also be considered in the context of the rituals of confrontation which sought to prevent the escalation of violence. Every step in the confrontation was fined differently, and fines were not deviated from. The occurrence of a wounding meant that a conflict had moved far beyond its initial stages in which opponents were offered de-escalation opportunities on a number of occasions, potentially with the help of bystanders. Individuals who let conflicts get out of hand received high fines without recourse to a flexible application of these, or alternative punishments. No specific circumstances were taken into account, apart from the aggravating ones in which an act was committed. As such, there was a clear link between the offence and the punishment, and it was obvious that every offender was expected to take direct responsibility for their act. At the same time, when a fine was paid immediately, the offence had no further repercussions. ${ }^{26}$

Violence was not an offence that constituted an obstacle to life in the community. ${ }^{27}$ The judgement of immoral behaviour was quite different in this respect. In such cases, the magistrates were much more flexible in their punishment. This was perhaps because such behaviour could be considered an obstacle to life in the community, at least from the perspective of the culprits' neighbours who denounced them. At the same time, the failure to take responsibility for violent acts (which could, of course, simply be an inability to pay a high fine) also resulted in an exclusion from the community. However, it was not normally the violent act that was the problem, but rather the failure to pay. The link between morality and debt will be discussed further in Chap. 5 .

As a punishment, banishment was common especially in cases of sexual misconduct or other behaviour considered to have been immoral as recorded in the Digestum Vetus and the Liber Causarum. These were cases that were generally decided before the full council and were thus apparently considered to require the full strength of 24 magistrates, as opposed to the fineable offences which were dealt with by the two burgomasters. The majority of banishment punishments (about two-thirds) were, however, recorded in the oerveden register. In these, it is not often detailed what the offenders were punished for. Most of those that do were for small

\footnotetext{
${ }^{26}$ There are a few exceptions in which individuals were banished for violent acts which led to potential maiming, such as Lubbert of Amersfoort who had hurt his victim's eye. Reg, p. 127 (1478).

${ }^{27}$ Concerning this, see Zaremska, Les bannis au Moyen Âge, 73.
} 
thefts (nine offenders), vagabondage (five men in a single case) and adultery (four people). Taking the cases from these registers together, banishment as a punishment was most regularly imposed for crimes against morality, followed by petty theft. This may have set in motion (or continued) a push towards a life on the road robbing and stealing. Such a life might ultimately lead to the gallows. Whether the casting out of vagabonds was a usual occurrence is not clear, as the five men who were banished for vagabondage were all evicted at the same time.

Banishment for petty theft was not uncommon in late medieval and early modern Europe. It has also been recorded in medieval Ghent, SaintQuentin and Poland, and in early modern Turku, Scotland and Augsburg. ${ }^{28}$ In addition, it became more common for people to be banished for vagabondage, potentially combined with transient theft, in the early modern period, such as in Turku, Augsburg and Ulm. ${ }^{29}$ Kampen was also not alone in banishing sexual offenders. This was, for example, evident in Turku for outsiders (insiders were fined or received penance), in medieval Poland, and in early modern Scotland, Augsburg and Ulm (especially of citizens). ${ }^{30}$ In some places, individuals were banished outright for violent behaviour, such as in medieval Poland and Saint-Quentin, and in early modern Ulm. ${ }^{31}$ In Ghent, banishments were used as reduced punishments for very young or very old culprits. ${ }^{32}$ Banishments were also used as coercive measures in different places in Europe, such as medieval Deventer, Saint-Quentin and early modern Augsburg. ${ }^{33}$ In medieval Cracow, banishment was also used to force a culprit to start negotiations after a manslaughter. ${ }^{34}$ In other places, individuals were sometimes required to pay a sum of money in

\footnotetext{
${ }^{28}$ Van Eetveld, 'Vrouwencriminaliteit', 32; Hamel, 'Bannis et bannissement', 130; Zaremska, Les bannis au Moyen Âge, 132; Laitinen, 'Banishment', 552-3; Ewan, 'Crossing borders and boundaries', 240; Tyler, 'Refugees and reform', 92.

${ }^{29}$ Laitinen, 'Banishment', 552-3; Tyler, 'Refugees and reform', 87; Coy, Strangers and Misfits, 30.

${ }^{30}$ Laitinen, 'Banishment', 555; Zaremska, Les bannis au Moyen Âge, 132; Ewan, 'Crossing borders and boundaries', 240; Tyler, 'Refugees and reform', 87; Coy, Strangers and Misfits, 29, 81 .

${ }^{31}$ Zaremska, Les bannis au Moyen Âge, 131, and Jeziorski, 'Die Strafe der Ausweisung', 37; Hamel, 'Bannis et bannissement', 130; Coy, Strangers and Misfits, 29.

${ }^{32}$ Van Eetveld, 'Vrouwencriminaliteit', 32.

${ }^{33}$ Benders, Bestuursstructuur, 175; Hamel, 'Bannis et bannissement', 124-5; Hoffmann, 'Der Stadtverweis', 224.

${ }^{34}$ Zaremska, Les bannis au Moyen Âge, 130.
} 
order to return after an exile, such as in medieval Fritzlar and Ghent. ${ }^{35}$ Throughout Europe, banishments were mostly imposed in cases of petty theft, vagabondage and sexual offences. In addition, perpetrators of violent crimes regularly ended up ousted from communities, either directly, or as a result of flight or the non-payment of the associated fine. As such, individuals were banished for a wide range of crimes. As others have also concluded, banishment was a very flexible punishment and measure which could be used for different purposes and in various different guises, and which was cheap to execute. It was also easily reversible and, especially when it was not combined with ritualistic displays, did not permanently damage a culprit's reputation. ${ }^{36}$

Sometimes, banishments in Kampen were imposed together with other punishments. These cases are found in the oerveden register. It seems that a group of men and women were caught following their fineable or other offences and put in custody. They were subsequently made to swear an oath before they were subjected to a punishment such as banishment or a flogging and banishment. The possibility to be subjected to a flogging in addition to banishment was a likely incentive for people guilty of fineable offences to flee. Of course, there were plenty of others who were not imprisoned before paying their fine, probably because they found people to vouch for them, but the threat of imprisonment and flogging was likely enough of an incentive for someone to choose to flee the town and negotiate the payment of a fine from elsewhere.

There were also a few individuals charged with adultery who were kept in custody and then were punished in accordance with the by-laws by being subjected to the 'kaak' and paying an $80 \mathrm{lb}$. fine. In 1469, for example, Johan Claesz the fuller and Bettken a wool comber swore an oath after having been found in adultery and spending time in custody. They were put on the 'kaak' and were subsequently banished for their $80 \mathrm{lb}$. fines. Johan had to stay at a distance of ten miles on pain of losing his hand, while Bettken was only banished from the town freedom until she could pay. ${ }^{37}$ Neither seems to have returned to Kampen, as the entry remains undeleted. A similar case is that against Thijs, the son of Jacob

${ }^{35}$ Von Brockdorf, 'Die Strafe desStadtverweises', 49; Van Eetveld, 'Vrouwencriminaliteit', 10.

${ }^{36}$ Coy, Strangers and Misfits, 15, 111. Concerning flexibility, see also, for example, Zaremska, Les bannis au Moyen Âge, 74; Maurer, 'Erzwungene Ferne', 201; Von Brockdorf, 'Die Strafe des Stadverweises', 53.

${ }^{37}$ Reg, p. 10 (1469). 
Boymansz, and Mense, the daughter of Henric Buysks. In their case there is no specific mention of imprisonment, but seeing that the oath was taken to prevent revenge after a stint in prison, Thijs and Mense most likely were kept in custody for a time too. In this case, there is no mention of a fine either: Thijs was sentenced to a banishment at a distance of five miles (on pain of losing his hand) and Mense at a distance of one mile on pain of carrying the stone. ${ }^{38}$ It is notable that in these cases the women were allowed to stay closer to the town. This could be construed as having been a slightly lighter punishment, but it may also indicate that the magistrates appreciated that a banishment was riskier for a lone woman than it was for a lone man. As we will see below, men were not normally punished more harshly for sexual crimes.

Other offences that could be punished with banishment according to the oerveden register were meddling in counterfeit goods, defamation and begging using false documents. In the latter case, the culprit had spoken 'dishonourable words of defamation' ('oneerlike woirde van diffamacie') about monasteries and clerics, obviously more serious insults than those usually fined with 2 or $10 \mathrm{lb}$. It might well be that the woman who had spoken these words, Henric de Kemmester (a wool comber?), already had a bad reputation and few respectable people that could or were willing to vouch for her, as she was made to keep a distance of at least five miles without any reprieve. ${ }^{39}$

There are a few other cases of individuals, likely of marginal status for whatever reason, who were punished differently by the Kampen magistrates. In 1455 a man known as the 'limping man' ('dat hinkende manneken') was punished for a number of offences. It was known that he had killed a man in Emmerich before. He was now flogged for wounding a man in his hand, throwing a stone at another man's chest and hurling rocks at a glass window. A vivid image of a man seemingly only wearing a garment covering his nether regions tied to the pillory and flogged by the executioner with a birch rod accompanies the entry. The man's back is marked by the beating (see Fig. 3.3). ${ }^{40}$ But apparently the flogging did not have the desired effect ('mer hee was doef daer um') and he was banned from the town. So, in this case, the court did not go the usual route of fining, nor does the case appear to have been dealt with by the burgomasters, as was

\footnotetext{
${ }^{38}$ Reg, p. 15 (1479).

${ }^{39}$ Reg, p. 20 (1487).

${ }^{40}$ DV, f. 16v.
} 
the norm for fineable offences. Instead, the man, who was marginalised even by the simple act of only referring to him as 'the limping man', was flogged, and only when that did not help, finally banished. It seems, then, that the council wanted to make an example of this man by flogging him publicly and perhaps literally beating him into submission. But it seems that this public ritual did not go according to plan, perhaps because the man only became less submissive as the beating went on. Gerd Schwerhoff has already pointed to the risks of public shaming in that a delinquent might use the podium for their own devices, and spectators could potentially turn on the magistrates. ${ }^{41}$ In this case, it appears that the magistrates managed to regain control of the situation when, as the final act, the man was cast out, likely accompanied by the same magistrates, the executioner, crowds and lots of noise.

Others were marginalised by their names too. In 1457 a woman referred to as 'raging Jutte' ('rasende Jutte') appeared before the council. It was reported that she had already received a warning in 1453 for adulterous behaviour, but that she was found in adultery again by the councillors themselves who she apparently showed her behind in an act of defiance ('liet onse raetsvrende in den stert sien'). In addition, her neighbours complained to the council about adultery, procuring and similar things. She was put in custody awaiting a punishment on the 'kaak' or carrying the stone, in accordance with the warning that she had received in 1453 . But on the next court day, the councillors had changed their minds and banished her instead. ${ }^{42}$ In this case, we do actually know Jutte's full name. She appears on an undated list of couples who were probably thought to be adulterous as Jutte van Ors op den Bilt, together with a man called Ludeken. A note was added to their names saying 'Dat is rasende Jutte' ${ }^{43}$

A final case that should be mentioned in this context is from the same period as the previous two, but in this case the individual was not banished. In 1456 it was unanimously decided that Jelle, whose portrait accompanies the text, should be put in the 'Wulentoerne'. Jelle, whose name suggests a Friesian heritage, had inflicted a punch on a man known as the duke of the Orient in a tavern, so that the victim had lost two teeth and gained a very ugly face ('een alteleliken aensichte'). ${ }^{44}$ Again, normally such an offence should have been dealt with by the lower court and have

\footnotetext{
${ }^{41}$ Schwerhoff, 'Verordnete Schande?', 173.

${ }^{42}$ DV, f. 27 r (28 June 1457).

${ }^{43} \mathrm{DV}$, f. 2 lar-v.

${ }^{44}$ DV, f. 22r (January 1456).
} 
resulted in a fine. In this case, though, Jelle was not flogged or banished, but he was locked up in a tower. It seems that Jelle was a character that the magistrates did not want to cast out of their community completely, perhaps because of a mental disability. If that was indeed the case, and perhaps depending on the severity of this disability, Jelle may have been locked up indefinitely in this tower, which is not mentioned anywhere else. He does not reappear elsewhere in the sources.

So occasionally the council deviated from the usual course of action in their punishment practices, apparently when it concerned particular marginal individuals. In addition, the magistrates on occasion appeared to marginalise people through their naming practices. Today we are used to courts and official institutions only utilising our full names, but in the later middle ages there were, of course, no standard naming practices. Nonetheless, the use of nicknames like 'rasende Jutte', adding a pejorative adjective to someone's name, suggests a bias that can only have influenced decisions negatively. ${ }^{45}$ At the same time, we see that Jutte was not punished on her first conviction; she received a warning and was only actually punished four years later when her continued immoral behaviour was a source of concern to both council and neighbours. This is a topic that I will return to below when discussing social status.

\section{Punishment Versus Coercive Measure}

The cases of outright banishment can be characterised relatively straightforwardly as punishments. The offenders had violated the town and town community's formal and informal rules and were punished by being excluded, either temporarily, permanently or until further notice, from this community. The use of additional punishments, which were mainly corporal and/or shameful, served to further stress and make public this exclusion. Mutilation marked offenders for life, making it difficult not only to re-enter Kampen society, but to join any community.

The other banishments are more difficult to characterise, also because it is impossible to recognise the sequence of events in many of the cases. Did offenders flee immediately after their offence, did they leave when they were charged or were they banished after their conviction when they

\footnotetext{
${ }^{45}$ Arnade and Prevenier, Honor, Vengeance, and Social Trouble, 181, noted that certain labels attached to people, such as prostitute, actress, wife or harlot, fixed their identities and assigned to them certain 'motives, justification and culpability'.
} 
were unable to pay their fine? In some cases, it is likely to have been the latter option, as in these cases their fine might have been listed among other fines initially, with the note 'uutg' added later. The same is the case for some of the entries recorded in the oerveden register. For the offenders not listed in either of these sources, it is likely to be one of the other two options. The question is whether we should consider the banishment in these cases as a coercive measure or as a punishment.

Richard Ireland and Guy Geltner have argued that imprisonment for debt should not be considered as a purely coercive measure. Debt, be it private or public (including fines), was 'viewed as a form of sin or social offence which merited punishment'. ${ }^{46}$ As such, debtors were not imprisoned solely to coerce them into paying, but also to punish them for their breach of faith. In addition, as Geltner argues, the premise of coercion is that the object is reluctant to do something. But poorer inmates were often incapable of ever paying off their debt or fine rather than being reluctant but, nonetheless, were imprisoned for life. ${ }^{47}$ The same can be said for banishment, although there is a marked difference between being held in one place until a debt was paid, or being wholly excluded from a space. In both cases, an offender could no longer conduct their activities in the same fashion as before. As a convict, however, they were not excluded from their community entirely, but rather contained. As Geltner states, they were marginalised, but not liminalised. In this way, urban magistrates could maintain social order without excluding a convict completely. ${ }^{48}$

For an exile, the exclusion was more or less complete, though perhaps temporary, but there were also options to start afresh in a different place. Exiles were also more mobile. This mobility can make us question the efficacy of using banishment as a coercive measure and, as such, whether the magistrates used it as such, or at least whether they used it as such for everyone. As was suggested by the evidence from the oerveden register, not everyone was offered the possibility to redeem themselves. Of course, for those who had built up a life in Kampen and had strong ties to the town and the community, a banishment may have been effective in

${ }^{46}$ Ireland, 'Theory and Practice', 57.

${ }^{47}$ Ibid.; Geltner, The Medieval Prison, 52-3, 101.

${ }^{48}$ Geltner, The Medieval Prison, 4, 106-8, referring to this practice as 'rough tolerance'. For the conceptual relationship between banishment and imprisonment, see also Van Caenegem, Geschiedenis van het strafrecht, 228. 
coercing them to pay (or to arrange for a payment in terms). It is different for those who did not have such strong ties. These men and women might have decided to build up a life elsewhere and it is likely that the town magistrates were not sorry to see them go if this was the case. Banishment then became a method to get rid of the undeserving poor. Poverty in itself was not a reason to exclude defaulters permanently. As will become clear in Chap. 5, the magistrates were flexible in arranging terms. A final consideration concerning coercion is that one can wonder to what extent one can coerce someone who no longer resides in one's jurisdiction.

The banishment for failure to pay a fine was therefore probably largely punitive. Of course, the non-payment of fines did not constitute a breach of faith in the same way that the non-payment of a debt did. But being part of the town community meant an agreement to abide by its formal and informal rules and to take responsibility when breaking them. As such, a failure to pay a fine and, ergo, to face up to one's responsibilities could be considered a breach of faith. Of course, such responsibilities were much easier to keep when one's finances were stable, and one had an extensive network.

It could be argued that the failure to pay a fine meant that an offender could not be punished in accordance with the by-laws. Banishment could then be considered an alternative punishment for the original offence. But in many cases, offenders were still expected to pay the full fine in order to be allowed to return. So, rather than being an alternative punishment for the original offence, it figured as a punitive measure for the failure to pay. This is also how it is portrayed in the town's by-laws, according to which a flogging needed to precede the lawbreaker's banishment (although this flogging appears to be largely absent from legal practice in the second half of the fifteenth century). However, in some cases banishment for unpaid fines may actually have acted and/or have been meant as an alternative punishment. When culprits in the oerveden register were told not to return after failing to pay a fine, the banishment was likely to have been considered as an alternative punishment.

Comparing the situations of debtors in Kampen and Italy, the former were better off as soon as they had arranged for repayment as they then became full members of urban society once again. This is opposed to most Italian debtors who remained in prison until their debt was paid off completely or a certain time had passed. ${ }^{49}$ In Deventer, too, debts appear to

${ }^{49}$ Geltner, The Medieval Prison, 58-60. 
have been expected to be paid in full before an exiled person was allowed to return. ${ }^{50}$ While banished, the Kampen exiles were most likely worse off: living a life of insecurity outside the safety of the town bounds, without their social network to protect them. Geltner has argued that, contrary to the bad press that they have generally received, medieval prisons were no 'hellholes' ${ }^{51}$ Prisons were situated in the medieval city and inmates had more ready access to friends and family than exiles did. Of course, prison life was still fairly unpleasant, but overall, probably less risky than being banished.

\section{Distance, Duration and Additional Punishments}

The banishment register does not include information on the duration of exiles or the distance that the banished had to keep from the town. Presumably there was a set distance, most likely outside the area of the town freedom, or one mile beyond that, the so-called banmijl. This banmijl radius also appears to have been used in at least two other towns in the lordship of the Utrecht bishop: Utrecht and Deventer. ${ }^{52}$ In addition, the banishment would remain valid until the fine was paid. There is no indication anywhere in the sources that a certain time away from the town could redeem any amount of fine. This does not necessarily mean that a period outside the town walls could not replace a low fine, but there is simply no information available anywhere in the sources. The possibility to replace a fine with banishment did exist elsewhere in the Netherlands: in Dordrecht every 6 months of banishment was worth 40 'Holland schellingen'. In Utrecht it was possible to choose a banishment for a restricted period instead of paying a fine for gambling. ${ }^{53}$

The banishments which were meted out as punishments mostly did include notes on the distance from the town and about a third also on the

${ }^{50}$ Benders, Bestuursstructuur, 177.

${ }^{51}$ Ibid., 80.

${ }^{52}$ Berents, Misdaad in de Middeleeuwen, 48; Benders, Bestuursstructuur, 177. The medieval mile in the Netherlands was much longer than the current mile. It is considered to have been the approximate distance that a person could walk within one hour, that is approx. $5 \mathrm{~km}$, but the distance varied throughout the Netherlands. Cf. the different miles used in Germany and Switzerland, Marchal, 'Von der Stadt', 245. In medieval Ghent (and presumably the other Flemish towns) people were banished not from the town but from the county of Flanders as a whole. Eetveld, 'Vrouwencriminaliteit', 9.

${ }^{53}$ Van Herwaarden, Opgelegde bedevaarten, 298; Berents, Misdaad in de Middeleeuwen, 48. 


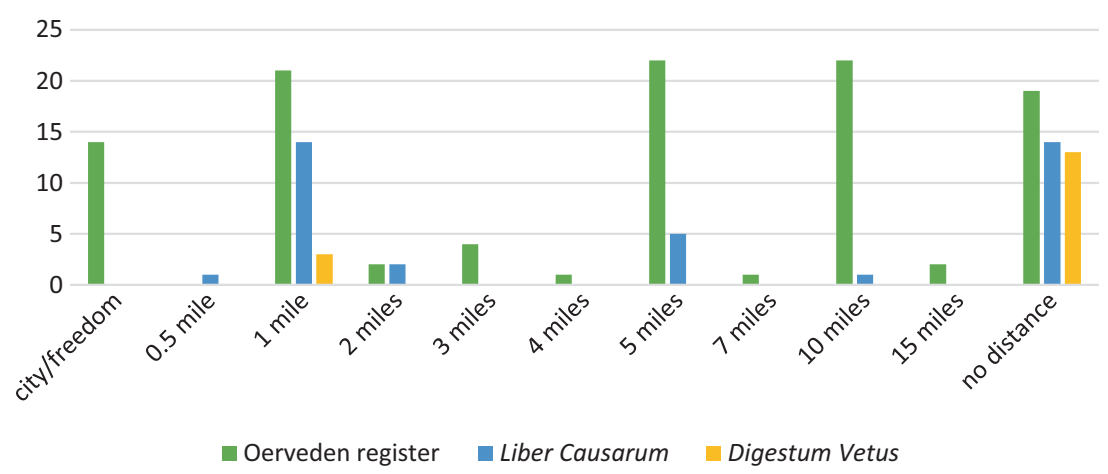

Fig. 4.1 Distances of banishment in different registers

duration of the stay. The distance ranged from outside the town or town freedom to 15 miles (see Fig. 4.1). ${ }^{54}$ There is a lot of variation in the distances, but the most commonly used were one mile, five miles and ten miles, in addition to a banishment from the town or town freedom. There is also a significant number of entries which does not include a distance. Distances in miles were used elsewhere in Europe too: they were common in German and Swiss towns, for example, but town magistrates there also indicated distance in different ways. In some cases, features in the landscape were named, such as rivers or mountains, and in others legal boundaries beyond the town, which were often indicated by physical markers such as stone crosses or pillars, were used. There could be great variation in the distances thus indicated, from nearby to faraway rivers and mountains, sometimes up to 150 or even 200 kilometres away. Some were banished across the Alps into Italian-speaking territories. The added advantage of physical features in the landscape was that they were easily recognisable which made it difficult for exiles to talk their way out of being found on the wrong side of them. ${ }^{55}$ Such variation is not recorded in Kampen and it is unknown whether any physical markers were erected to indicate the 'banmijl' or other distances.

\footnotetext{
${ }^{54}$ Almost all of the entries in the oerveden register and the Liber Causarum include a distance, whereas only three entries in the Digestum Vetus contain this information. The latter two only rarely include a note on the duration.

${ }^{55}$ Maurer, 'Erzwungene Ferne', 202, 205-6; Marchal, 'Von der Stadt', 229, 245.
} 
It is also unclear whether there was any mechanism in place to monitor or enforce the distances exiles were supposed to keep from Kampen, especially seeing that the area beyond the town freedom was outside its jurisdiction. ${ }^{56}$ Helmut Maurer has argued that the longer distances were meted out to also protect the towns' hinterlands. ${ }^{57}$ But, as Guy Marchal has pointed out, it is unlikely to have been possible to know exactly how many miles a place was from the town bounds. Rather, these miles indicated either shorter or longer distances that outcasts needed to keep from town and, as such, signified a less or more significant exclusion from the town community ${ }^{58}$ Nonetheless, it needed to be possible to enforce the various verdicts. Amsterdam for that reason apparently requested from Charles V that milestones be placed around the city, so that distances could be more easily enforced, and exiles would not have an excuse when they were found too close to town. ${ }^{59}$ This suggests that policing forces were dispatched to monitor the presence of banished individuals. In cities like Bamberg, Nürnberg, Speyer and Ulm, too, soldiers were sent out on surveillance to check the roads leading from the city, as far as 50-60 kilometres away. As the neighbouring regions were generally subject to noble lords, agreements were set up for the specific purpose of capturing exiles who stayed in the area illegally. ${ }^{60}$ It may well be that similar checks were conducted from Kampen, though there is no evidence that anyone was caught outside the town bounds in an area that was off-limits to them. The indication of distances in the sources and the monitoring of these suggest that people were expected to have some sense of geography and distances. As Marchal has stated, the sources that survive were written by those in power, but in order to be able to enforce the verdicts, they needed to have been understood by those who they concerned. ${ }^{61}$

The duration of stay was less straightforward than the distance. A few were banished from Kampen for five or ten years. Others were banished until further notice (occasionally it stated specifically: until messengers were sent to get them back), until the offender learned to behave themselves or until a fine was paid. So, these all correspond to Hoffmann's temporary exiles. There were also banishments without further

\footnotetext{
${ }^{56}$ Coy, 'Beggars at the gates', 637.

${ }^{57}$ Maurer, 'Erzwungene Ferne', 203.

${ }^{58}$ Marchal, 'Von der Stadt', 249.

${ }^{59}$ Maurer, 'Erzwungene Ferne', 203.

${ }^{60}$ Ibid., 203-4.

${ }^{61}$ Marchal, 'Von der Stadt', 225-6.
} 
specification: in one or two cases there was no mention of distance or duration of stay, and in others there was only a very general statement that someone was banned ('der stad verboden', 'uutgelacht', 'niet weder comen', the last of which suggests a banishment for life). Finally, there were some who were banished permanently. These were cast out either for life or for eternity. The difference may lie in the question whether or not an exile could be buried in Kampen after their death or not, though it may be that there was only a symbolic difference between the two. This variation in duration existed elsewhere too, but there are clear differences in the general practices locally. In Cracow, in the late middle ages, for example, banishments were mostly for life on pain of capital punishment. There were some which were shorter, like six months, one year or ten years, but the majority were sentences for life. ${ }^{62}$ In medieval Ghent, individuals were mostly sentenced to very long banishments, with an average of 50 years, but ranging from three years to eternally. However, many apparently negotiated a return against payment within two to three years. ${ }^{63}$ In medieval Saint-Quentin, manslaughterers who fled were exiled eternally, but those convicted for moveable debts or thefts received a temporary banishment. ${ }^{64}$ In Luzern, banishments were mostly in months, rather than years. ${ }^{65}$ Overall, then, it is difficult to discern a shared legal culture when it comes to the duration of banishment and its relation to various crimes.

The banishments recorded in the oerveden register were mostly meted out after the offender had already spent some time in prison. In total 43 of 108 persons that were banished according to this register also received additional punishments, especially floggings, but also public punishments on the pillory ('kaak'), the cutting off of an ear (or part thereof) or branding. ${ }^{66}$ Ears were always cut off as a punishment for theft, but some thieves were just flogged. The pillory was generally used for adulterers, although a counterfeiter was also displayed on the pillory wearing a paper hat, before being banished for eternity and at a distance of ten miles. ${ }^{67}$ The

${ }^{62}$ Zaremska, Les bannis au Moyen Âge, 132.

${ }^{63}$ Van Eetveld, 'Vrouwencriminaliteit', 9-10.

${ }^{64} \mathrm{Hamel}$, 'Bannis et bannissement', 125.

${ }^{65}$ Marchal, 'Von der Stadt', 241.

${ }^{66} \mathrm{It}$ is noteworthy that no banishments were recorded in the oerveden register after 1491. There is no sign of any abating of banishments in the other registers.

${ }^{67} \mathrm{Reg}$, p. 14 (30 September 1476). This is the only time that the punishment of wearing a paper hat is mentioned anywhere in the sources. 
punishment for counterfeit goods was also meted out at the pillory: one offender's wool combs were burnt there before he himself was banished. ${ }^{68}$

From 1464 onwards especially (only rarely before) a majority of oathtaking exiles also received a warning not to return to Kampen during their banishment on pain of various punishments, many of them corporal or capital. This deviates from the general rule of an $80 \mathrm{lb}$. fine as discussed above. There is no clear correlation between the distance of the banishment and the seriousness of this warning, though long distances (10 or 15 miles) were only ever combined with capital punishment, or the cutting off of ear or hand. Short distances were, however, also combined with capital punishment. ${ }^{69}$ There is no evidence that such punishments were actually executed, but that may be because none of the exiles actually returned. Similar threats or regulations existed elsewhere: in medieval Saint-Quentin harsh punishments were meted out for illegal returns. ${ }^{70}$ In medieval Ghent, capital punishment was laid down for the breaking of eternal banishments and actually executed. ${ }^{71}$ In medieval Valenciennes, the threat was not a corporal or capital punishment, but a permanent banishment. ${ }^{72}$ These threats have in common their aim: trying to convince exiles not to return.

\section{The Role of Gender and Morality}

Considering all banishments, the proportion of women who were exiled was only small: 152 out of the 1446 offenders in Table 4.1 (10.5 per cent). In the register of banishment, the numbers are even lower: 90 out of 1285 ( 7 per cent). This is because many more men were fined, and the highest fines were also mainly incurred by men, for various forms of violence. Nonetheless, about a third of the women in this register were also banished after failing to pay a fine dealt out for violence. ${ }^{73}$ The proportions in the other three registers are very different. In the oerveden register almost a quarter (23.1 per cent) of the banished were women, in the Digestum Vetus more than a third (37.5 per cent), whereas in the Liber

\footnotetext{
${ }^{68}$ Reg, p. 1 (18 December 1447).

${ }^{69}$ Offences are mentioned too irregularly to be able to establish any correlation between crime and conditional punishment.

${ }^{70} \mathrm{Hamel}$, 'Bannis et bannissement', 130 .

${ }^{71}$ Van Eetveld, 'Vrouwencriminaliteit', 125.

${ }^{72}$ Huart, 'Maintenir la paix', 14.

${ }^{73} \mathrm{~A}$ small majority of these cases concerned violence against other women.
} 
Causarum it was almost three-quarters (73 per cent). As a primary punishment, therefore, banishment was dealt out to relatively many women; 62 out of 161 banished offenders were female (38.5 per cent).

This high percentage is due to the fact that banishments were often administered as a punishment for sexual offences, offences concerning which relatively many women were charged. Of the ten cases in the oerveden register in which a crime perpetrated by a woman is mentioned, five had been meted out for adultery and one for procuring (of the other four, two were for theft, one for defamation and one for violence). In the Liber Causarum 19 out of 27 women had been punished for adultery or facilitating prostitution (against two out of ten men). ${ }^{74}$ Nine out of ten women (against three out of six men) in the Digestum Vetus had been sentenced to banishment for sexual offences, the tenth not mentioning a crime. In a number of cases of adultery only the woman was banished; the man got away with a warning.

In fact, in many cases of sexually offensive conduct, the offenders received warnings, both men and women, despite the relatively hefty punishments laid down in the by-laws. Several by-laws were recorded in the town registers in the second half of the 1450s, especially around the times that the Franciscan Observant friar Brugman visited the town in 1455 and 1458 and preached against lewd priests, immoral town councils, adulterers, drunks, gamblers and prostitutes. ${ }^{75}$ The by-laws proscribed adultery and 'kwade herberg' ('bad inn': facilitating illegal sexual acts) on punishment of banishment or the 'kaak' and a fine of $80 \mathrm{lb}$. each. ${ }^{76}$ Nonetheless, in 1463 two women named Swarte Gese and Assele (see Fig. 4.2) were given a warning for 'kwade herberg' and procuring. ${ }^{77}$ Similarly, Herman Druuchschere and his wife Hille (see Fig. 4.3) were given a warning in $1467 .{ }^{78}$ All four offenders are portrayed by the clerk in images accompanying the entries. Apart, perhaps, from Hille, all have lowered heads,

${ }^{74}$ Two of the 19 were in combination with misbehaviour.

${ }^{75}$ DV, f. 19v (1455), f. 31r (1458). Brand and Frankot, 'Das Kampener Stadtbuch', 58-59. Between 1455 and 1463 Brugman visited a large number of towns in various parts of the Netherlands, where he preached for hours. With regard to his sojourn in Bolsward in 1455, see Robijn, Het recht van een vrije Friese stad, 99-103. More generally, see Lettinck, Praten als Brugman.

${ }^{76} \mathrm{DV}$, f. $2 \operatorname{lr}$ ( 5 December 1455; three by-laws, one of which was subsequently deleted); $\mathrm{f}$. $2 \operatorname{lv}$ (18 December 1455); f. 2lv (20 December 1455); f. 30v (1 July 1458).

${ }^{77}$ DV, f. $54 \mathrm{r}(1463)$.

${ }^{78}$ DV, f. 75 v (23 May 1467). 


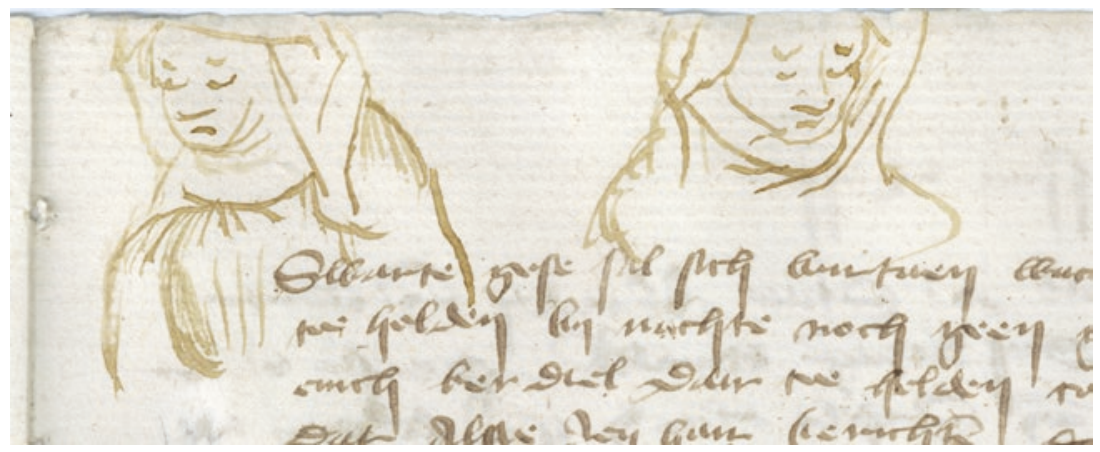

Fig. 4.2 Swarte Gese and Assele (DV, f. 54r (1463)). (@ Stadsarchief Kampen, Nederland/@ City Archives Kampen, the Netherlands)

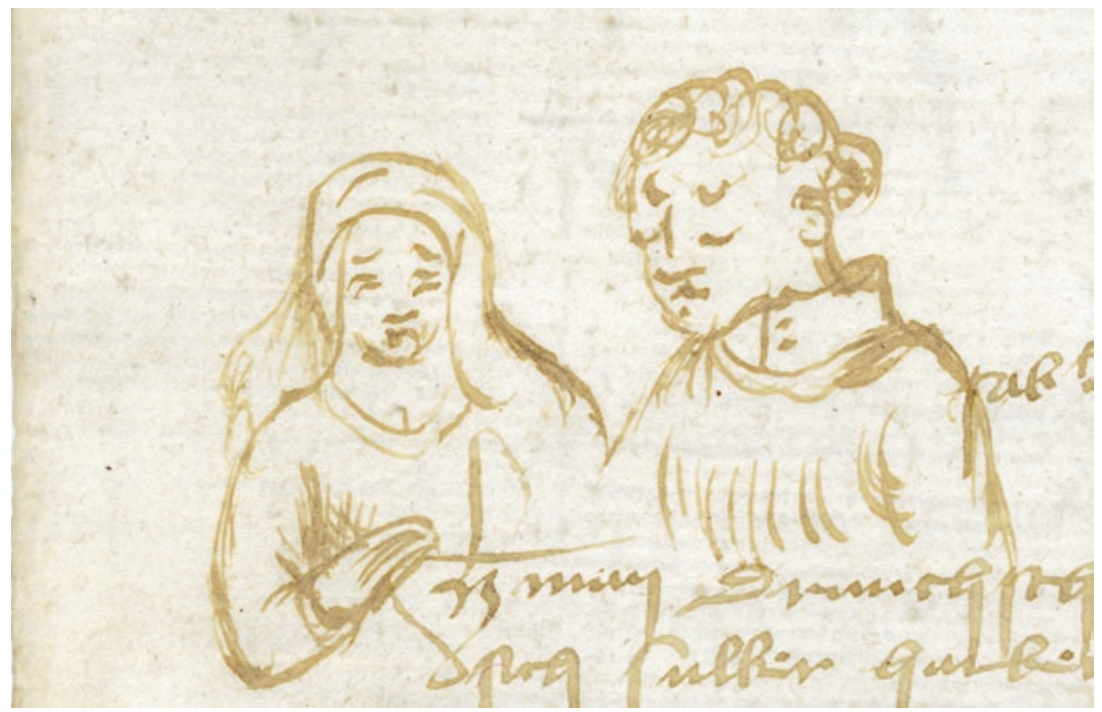

Fig. 4.3 Herman Druuchschere and Hille (DV, f. 75v (23 May 1467)). () Stadsarchief Kampen, Nederland/(C) City Archives Kampen, the Netherlands) 
presumably to suggest their humility before the court when receiving their warnings.

In court, sexual offenders were given warnings, as were others who misbehaved, especially those accused of domestic violence. ${ }^{79}$ These warnings sometimes included specific punishments that would be inflicted on repeating an offence, but at other times would be vaguer, as indicated earlier. Terms such as 'the offender will be punished so that they will figure as an example (or a mirror) to others', 'the court will consider the punishment', 'the offender will be sentenced harshly' or 'the offender shall not know their punishment' were used. This suggests that the court often judged people on a case-by-case basis and took personal circumstances into account. ${ }^{80}$ Such flexibility in judging is also in evidence elsewhere, such as in early modern Ulm, where the court took into account various personal circumstances. ${ }^{81}$ Unfortunately, in Kampen these circumstances are not often quoted, and we are therefore mostly left in the dark as to why one person was let off easily, whereas others were punished more harshly. For example, in 1484 Johan Fedde and his wench (in Dutch the word can be used for both servant and prostitute) confessed to having committed adultery. A child was also born from this union. The council decided that the two could not remain in Kampen any longer and had to distance themselves two miles from the town jurisdiction. ${ }^{82}$ In 1492, on the other hand, it was decided that Cornelis van den Busch, the husband of Mette Busen, and Large Gerryt, the wench, should no longer have any contact, in any sense of the word, and that Cornelis should live peacefully together with his wife like a good husband was expected to do. If they were caught again, they would be punished shamefully on the 'kaak' to set an example to others. ${ }^{83}$ It may be that Johan Fedde's affair had been going on for longer-the evidence of a child born from their union certainly suggests this-but there may also be other reasons for the difference in treatment.

At other times it is clear why someone was sentenced to be banished: a combination of crimes of adultery and procuring usually resulted in a

\footnotetext{
${ }^{79} \mathrm{Cf}$. with the magistrates of Leiden taking women into protection against aggressive men, Blockmans and Neijzen, 'Functions of fiction', 275.

${ }^{80}$ This flexibility of administering the law is mainly to be found in the higher court of aldermen. The lower court appears to have adhered strictly to the fines laid down in the bylaws. See also below.

${ }^{81}$ Coy, Strangers and Misfits, 25.

${ }^{82}$ LC, f. 16v (3 October 1484).

${ }^{83}$ LC, f. 34v (19 July 1492).
} 
banishment. In 1476, for example, the council decided that Mette van Epe was to leave the town within eight days and was not to come within half a mile of the town jurisdiction because she was known to have committed adultery with men other than her husband and she was also badly behaved and lived immorally, and was involved in facilitating illegal sexual acts. ${ }^{84}$

Nonetheless, it is clear that one of the aggravating circumstances for receiving harsher punishments was the simple circumstance of one's sex. As said, of 37 banishments that were imposed in the Liber Causarum, 27 were imposed on women, mainly for sexual offences, whereas only 2 men were banished for such offences. To this must be added, though, that more women were brought before the court for procuring and for a combination of prostitution and adultery, as well as for five unknown, probably sexual offences (as for all of them a banishment was imposed). ${ }^{85}$ This suggests that they were more regularly denounced than men, which may indicate a lower threshold for the disapproval of immoral behaviour of women. ${ }^{86}$ As such, they were also more likely to be ousted for such offences. But women were also banished six times for adultery, whereas only one man was punished that way, despite the fact that a practically equal amount of men and women was charged with this offence. ${ }^{87}$ This stricter punishment of women for adultery matches penal practices elsewhere, such as that in Konstanz, where women were often judged to have had a more active role than men. ${ }^{88}$ In medieval Ulm, there had also been an increased focus on sexual morality, but the issue was only taken up systematically after the Reformation. This resulted in an increase in punishment of sexual offenders, especially through banishment. The majority of women banished had been charged with immoral behaviour. ${ }^{89}$ It also appears that the Kampen town council became stricter towards

${ }^{84}$ LC, f. 6r (8 Oct 1476).

${ }^{85}$ According to the Liber Causarum, 45 women and 29 men were charged with adultery and/or facilitating prostitution or illegal sexual acts (including the five unknown sexual offences) between 1474 and 1500 .

${ }^{86}$ Lipscomb, Voices of Nimes, 89-90, 147-52, points to the importance of female networks and resulting gossip in the identification and prosecution of immoral behaviour, especially of women, in the Protestant consistory courts in Languedoc. Whether women were denouncing women in Kampen is unclear.

${ }^{87} \mathrm{~A}$ total of 27 men and 26 women appeared in court on a charge of adultery according to the Liber Causarum (1474-1500).

${ }^{88}$ Schuster, Stadt vor Gericht, 115-8.

${ }^{89}$ Coy, Strangers and Misfits, 65. 
facilitating prostitution and adultery in the fourth quarter of the fifteenth century. In the third quarter nobody was banished for holding 'bad inns' alone, whereas in the fourth quarter a number of people, mainly women, received this penalty for bringing together married people or women and priests for illegal sexual acts, such as Alijt Koggenstuers who was charged with holding a 'bad inn' and keeping married people away from each other. She was sentenced to a five-year banishment, a relatively long period. ${ }^{90}$ It is also noticeable that the number of men banished in the Digestum Vetus (1454-1473) and the Liber Causarum (1475-1500) was the same, whereas that of women increased from 6 in the Digestum Vetus to 27 in the Liber Causarum.

The fact that women were more often banished than men for sexual crimes may have been due to the fact that women were traditionally seen as the guilty party when it came to sexual offences. ${ }^{91}$ Also, in some cases of adultery the man probably had a higher status than the woman. As we have seen, some men had relations with their female servants. People with a lower social status would sooner be banished (and indeed, sometimes only the woman was banished in cases of adultery). People of higher status could also more easily afford to pay a fine. Another economic reason can perhaps also be given: the men would in general be working in a profession and had a family to provide for. As such, any banishment of a man would be detrimental to the whole household. In Amsterdam, female breadwinners were not sentenced to banishment for that exact same reason..$^{92}$

The increase in banishments for crimes against morality fits in with a general development in the later middle ages and leading up to the Reformation. In this period, there was a strong urban movement advocating public decency which was fuelled by the activities of Observant preachers like Bernardino of Siena and the already mentioned Brugman. It is probably no coincidence that by-laws regulating adultery and procuring

${ }^{90}$ LC, f. $45 \mathrm{v}$ (between 15 July and 17 October 1497). In Konstanz, too, magistrates dealt more strictly with morally offensive behaviour in the second half of the fifteenth century. Schuster, Stadt vor Gericht, 118.

${ }^{91}$ See, for example, Cohen, Crossroads of Justice, 85, 94-5; Crawford, European Sexualities, 172; Schuster, 'Hinaus oder ins Frauenhaus', 21; concerning concupiscence as associated with feminine nature, see Lansing, 'Gender and civic authority', 33, 40-5. See also the incarceration for sexual misconduct of women in early modern Marseille as analysed by Cattelona, 'Control and collaboration'.

${ }^{92}$ Boomgaard, Misdaad en straf in Amsterdam, 216. See also Berents, Het werk van de vos, 52-55; Brand and Frankot, 'Das Kampener Stadtbuch', 54. 
were promulgated less than two months after Brugman's first visit. There also appears to have been an increase in the prosecution of sexual crimes, though there are few sources from before 1455 to confirm there was a change. ${ }^{93}$ This morality movement was supported, or even initiated, by the members of the public, who were relied upon to bring forward complaints. According to the by-laws, those bringing charges would receive half the fine if the accused was convicted (and indeed in 1461 there were two people who received a quarter of the fine each in a case of adultery ${ }^{94}$ ). In addition, there is regular mention in the sources of complaints made by neighbours. ${ }^{95}$ The increase in prosecution was most likely largely the result of an increase in denunciations which indicate a growing focus on morality among certain groups in society. Initially, in the decades directly following Brugman's visits, many of the accused got away with a warning. It was only in the last quarter of the fifteenth century that there appears to have been an increase in punitive measures against female offenders especially. ${ }^{96}$ This was perhaps the result of increasingly clear signals from those who denounced their neighbours, that certain behaviour would no longer be tolerated. As studies of early modern towns such as Ulm and Augsburg have shown, the prosecution of immoral behaviour became more systematic after the Reformation. ${ }^{97}$ Moreover, honourable men and especially women found a new arena to showcase their concerns about immoral behaviour in the Protestant consistory courts, as Lipscomb has shown with regard to the Languedoc. ${ }^{98}$ In late medieval Kampen, the increase in banishments of women accused of immoral behaviour in the final quarter of the fifteenth century suggests a change in the perception of such acts among the magistracy, who in the previous quarter most likely already had had to deal with a growing number of denunciations. By the final

\footnotetext{
${ }^{93}$ There are three lists of sexual offenders in the Digestum Vetus, for example, two of which are from the 1460s and one which is undated. DV, f. 21 a (n.d.), f. 47a (1462), f. 78b (1468).

${ }^{94} \mathrm{DV}$, f. $44 \mathrm{v}$ (30 March 1461).

${ }^{95}$ See also Brand and Frankot, 'Das Kampener Stadtbuch', 57-9. In early modern Ulm, denunciation was expected, and people could even be reprimanded for failing to do their civic duty. But most people were happy to cooperate with the local authorities in order to maintain a godly order. Coy, Strangers and Misfits, 63, 86, 116.

${ }^{96} \mathrm{Cf}$. Brand and Frankot, 'Das Kampener Stadtbuch', 59.

${ }^{97}$ Coy, Strangers and Misfits, 65; Tyler, 'Refugees and reform', 86.

${ }^{98}$ Lipscomb, Voices of Nimes. The special role of women in policing women's behaviour has also been noted by Cattelona, 'Control and Collaboration', concerning early modern Marseille.
} 
quarter of the century, they became more prepared to also start sentencing more strictly.

This period also saw an increase in the focus on morality in the language used in the legal records. ${ }^{99}$ When comparing the Digestum Vetus and the Liber Causarum, there is a notable difference in the use of adjectives denoting acceptable and unacceptable behaviour and language. Words like 'oneerlike' (dishonourable), 'quellike' (unruly), 'myslike' (unreliable), 'quade' (bad), 'onhoefflike' (discourteous), 'schantelike' (shameful), 'onwijslike' (unwise), 'onredelike' (unreasonable), 'onbehoirlike' (improper) and 'onrustelike' (restless) are used more regularly in the Liber Causarum and are opposed to 'vredelike' (peaceful), 'rustlike' (calm), 'hoeffsche' (courteous), 'guede' (good), 'eerlike' (honest), 'sedichlike' (virtuous) and similar terms. For example, Grete Holle was said to live in a restless, dishonourable and unruly fashion with her neighbours, arguing, speaking ill and using dishonourable, discourteous and disgraceful words against them, calling and insulting them. She was warned against all of this and told to stop her inappropriate behaviour ('onmanierlicheit') as the council would no longer tolerate it and preferred to see her leave ('wil sie hier niet langer liden'). ${ }^{100}$ Dyrck up die Sluse had been behaving indecently, visiting other women at night and frequenting disreputable taverns ('oneerlijken herbergen'). In addition, he was living with his wife in a restless and unruly fashion, and he was hitting her. He was told to stop his indecent and dishonourable behaviour and live quietly and peacefully with his wife as he should ('als dat behoirt'). ${ }^{101}$ Other husbands (and an occasional wife) were also warned to 'do as a good husband (or wife) should do to his wife (her husband)'. ${ }^{102}$ Melijs Buth, finally, who was sentenced to be banished for two years, was charged with general misbehaviour: becoming increasingly more 'boeffliken en de schalckliken' (disgraceful or evil and bad or sinful), not making any effort to be good ('tot gienre doecht en schickt') and not obeying the good men who tried to council him. ${ }^{103}$ The absence of any specific offences is particularly notable in this case, especially considering his severe punishment.

\footnotetext{
${ }^{99}$ Concerning language in legal records and how it expressed perceptions, see also McIntosh, 'Finding language for misconduct' (pointing to an influx of unmarried outsiders perceived as threatening social order as an explanation for a change in language in market centre courts in the second half of the fifteenth century-p. 112); Hanawalt, 'Good governance', 248; Gauvard, 'De Grace Especial', 111-43.

${ }^{100}$ LC, f. 18v (July 1484).

${ }^{101}$ LC, f. 25v (20 June 1488).

${ }^{102}$ For example, LC, f. 14r: 'doen als en guet man bij sijnen wijve schuldich is toe doene'.

${ }^{103}$ LC, f. 24 r (26 November 1487).
} 
In addition to the use of legal terminology that is focused on morality, there is also an increase in cases in which behaviour, including the use of particular language, is considered to be offensive and worthy of punishment (or at least a warning in court). The wording 'soe en wil men sie hier inder stat niet lijden', moreover, confirms that offensive and immoral behaviour could ultimately lead to exclusion from the community. Worth noting in this context are certain comments on the effect that certain behaviour and language had on the good people of the town, or on the culprits' neighbours. For example, in 1492 Femme mitten Tanden's behaviour was said to sadden all good people and the neighbours ('soe dattet allen gueden luden ende den nabueren verdriet'). ${ }^{104}$

This supports the view already noted that the magistrates and the 'good people' of Kampen agreed on what was considered to be acceptable, honourable behaviour and that these good people expected the magistrates to take action. Occasionally, the magistrates can be seen to go beyond what was expected of them: in 1459, in a case of a man who treated his mother unreasonably, a note is included that perhaps his mother was willing to tolerate such behaviour, but that the council most certainly was not ('al woldet die moeder van hem lijden, die raet wils in geenrewijs van hem lijden'). ${ }^{105}$ Also, the magistrates can occasionally be seen to be prepared to punish miscreants more harshly than was detailed in the by-laws. Moye Geert in 1482 would, on continuing his misbehaviour, not be punished according to the 'gemene kuer' as others were, but in the sharpest way, on the decision of the aldermen. ${ }^{106}$ Such individually decided punishments ('ter scepen claringe') were also regularly said to act as an 'example' that is to say that they were expected to act as a deterrent. Through its practice of punishment and warning, the magistrates were thus explicitly communicating a message to the general population with regard to behaviour that could lead to exclusion.

Overall, it appears, then, that relatively many women were banished as a primary punishment. The behaviours that led to banishment from urban society, such as adultery and procuring, were those that were especially associated with women. In addition, women were more likely to be considered the guilty party in sexual crimes, and they were seen as less vital to

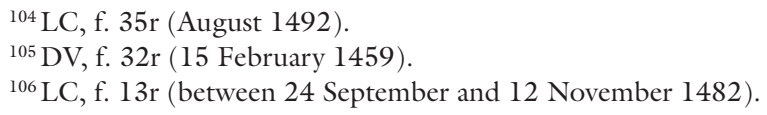


the urban economy. The vast majority of exiles were, however, men, as they were much more likely to be caught up in violent episodes, and because violence incurred the highest fines.

\section{The Role of Social Class}

The assessment of the role of social class in punishment is more difficult than that of gender, because it is often difficult, if not impossible, to gain social information on the offenders that feature in the sources. The profession of miscreants is only mentioned in some of the cases and last names may or may not provide clues about someone's activities. In some cases, someone's last name equates with their profession, but in other cases it does not. ${ }^{107}$ Similarly, toponymic surnames may or may not indicate a person's place of origin or residence. As a result, it is difficult to confirm whether such a person was a Kampen inhabitant or citizen or not. The citizenship administration is only extant until 1469.

Nonetheless, it is possible to draw some conclusions from the available material. In some cases, a person's description includes both a surname and a profession or a place name (or both). In the oerveden registers only very few entries include a profession (about one in nine). These are mostly craftsmen, particularly fullers and weavers, but also the executioner and a sexton. Professions are named about twice as often in the banishment register. There, too, many are craftsmen, but there is also a significant group of servants. Weavers and fullers again appear regularly, as do millers, tailors and smiths. These may well represent relatively large groups of Kampen society, which had a modest textile industry, but it is noteworthy that there is only one baker, when there are ten millers. ${ }^{108}$ On the other hand, as we do not have information on more than 75 per cent of the offenders, there are no major conclusions to be drawn on the use of

${ }^{107}$ For example, Goesen Holtsaeger (Wood sawyer) had two men standing surety for him, both called Tymmerman (Carpenter). Reg, p. 415 (1497). In that case, it is likely, though not definitely true, that all three names indicate a profession, as a wood sawyer would normally have had carpenters in his professional network. Johan Pelser, on the other hand, was not a furrier, as his name might suggest, but a fuller ('vulre'). Reg, p. 390 (1486).

${ }^{108}$ Weavers displaying disobedience also appeared prominently in the early modern Ulm records. Coy, Strangers and Misfits, 64. In fourteenth-century Zürich, tailors and millers are also regularly mentioned, as are shoemakers and butchers. Burghartz, Leib, Ehre und Gut, 100. Zaremska (Les bannis au Moyen Âge, 139) also notes the prominence of craftsmen and servants among the accused (and the victims) of violence. 
violence among groups of craftsmen (and their lacking ability to pay the relevant fines for this violence).

At least a quarter of offenders in the oerveden register was not originally from Kampen. This should not come as a surprise, as people from elsewhere were more likely to be put in custody and made to swear not to harm the town, because they would have had more difficulty in securing people who could stand surety for them. There are far fewer entries that include places of origin outside of Kampen in the banishment register. Seeing that the latter is generally more informative concerning its offenders, it is likely that relatively more offenders in the oerveden register were from out of town than in the banishment register.

In other cases, it is clear that someone was from Kampen, for example because a spouse is mentioned who also fell under the Kampen jurisdiction. For example, Maye, the wife of Willem Riemslager, was initially given grace from banishment (for adultery) because her husband declared himself willing to forgive her, and she was allowed to remain with him in Kampen. She was ultimately banished after all, after having been facilitated by three other women to lie with a clergyman in the bathhouse and bordellos during Lent. However, it is clear from the entry that she was a Kampen inhabitant. Judging by his name, her husband may have been a beltmaker. ${ }^{109}$

A number of the women who were banished also had toponymic surnames, or placenames attached to their names. Like with toponymics for men, it is not clear whether these women actually came from elsewhere. It is notable, however, that these women were not identified by either a husband or a father's name, like many of the other women in the sources were. So, they may well have been immigrants whose main point of identification was their origin, such as Lamme and Aelheit of Groningen, Lijse and Heyle of Nijmegen, Bethkyn Vos of Zutphen, Gertruidt of Essen and Griete of Bremen. Only one of these seven women was definitely married.

It is difficult to assess whether or not a woman's status as a married or unmarried woman affected their punishment. In fact, it is likely that in two cases, their marriage was actually a deteriorating factor in the sentencing of two women: Nase and Mette in 1474 and 1477 respectively were told to join their husbands who were already in exile. ${ }^{110}$ It may well be that these women had resorted to (facilitating) prostitution to make ends meet

\footnotetext{
${ }^{109}$ LC, f. 28v (April 1490); Reg, p. 22 (1490).

${ }^{110}$ LC, f. 2 r (13 October 1474); LC, f. 7r (22 November 1477).
} 
after their husbands' banishment. In the case of Maye, Willem Riemslager's wife (see earlier), however, her husband's mercy saved her from exile initially. It may well be that a husband's willingness to show such mercy was an important factor in the decision whether or not to banish women who had been charged with adultery or other sexual crimes. In early modern $\mathrm{Ulm}$, the wishes of a wronged spouse were also known to influence the sentencing. ${ }^{111}$ But there were also unmarried women who only received a warning, such as Quade Derixken, whose nickname 'Quade' suggests she had a bad reputation. She was charged with facilitating illegal sexual acts in December of 1475 and given a warning. She was ultimately banished after continued complaints from her neighbours, but that was not until April 1479. ${ }^{112}$ The before mentioned Ghertruidt of Essen was also given a warning after she had been found to live dishonourably with a priest in 1497. ${ }^{113}$ Maiken, on the other hand, who was said to be living with Willem van Essen, was banished in 1481. ${ }^{114}$ Unlike unmarried women, unmarried men were unlikely to be charged with sexual offences unless these were 'against nature', such as homosexual acts or bestiality. As such, an unmarried status was not a major factor in the banishment of males for immoral acts. Nonetheless, it is likely that a married man was considered differently by the court, because he had other responsibilities and was expected to act more responsibly. This can be expected to have affected his punishment both positively and negatively.

It is unclear whether a person's status as a burgher had any influence on their punishment or on the magistrates' perception of them. There is no specific mention of individuals' status as a citizen in relation to any verdicts or punishments, so we cannot establish either a positive or negative effect of this status. In addition, it is often difficult to determine whether someone was a citizen or not. The Burgerboek includes mainly names, many of them patronymics, and it is virtually impossible to link most of these to individuals that appear elsewhere in the sources. Either people had very common names, or they had non-patronymic aliases that were not noted in the Burgerboek. ${ }^{115}$ For early modern Ulm, Coy was able to differentiate between citizens, resident aliens and vagrants. Citizens tended to be

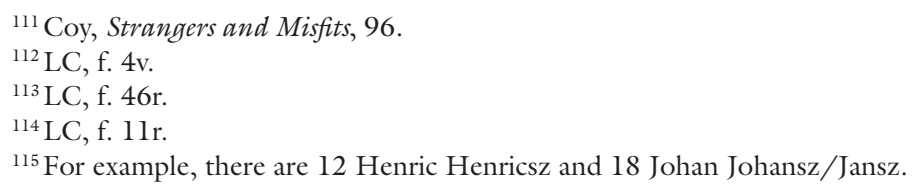


treated leniently initially. For adultery, for example, they received an eightday imprisonment and a verbal reprimand, but their conviction did not result in permanent dishonour. Instead, the magistrates aimed to save the marriage. Overall, citizens were much less likely to be banished than migrants and vagrants. Of citizens sentenced, only 26 per cent were ordered to leave town, against 37 per cent of resident aliens and 82 per cent of vagrants. Migrants were also subject to stricter laws from 1527 , especially concerning their fiscal and moral obligations. As a result of an economic downturn, the town had no qualms in ousting non-citizens who threatened the town's prosperity or morality. ${ }^{116}$

Usually, the only individuals in Kampen we can be certain were citizens are the members of some of the elite families, or the magistrates themselves. There were, for example, three members of the Van Uterwijc family who were banished in 1482 (Ruederic), 1493 (Herman) and 1496 (Wolter) respectively, all three for a wounding at night. ${ }^{117}$ Only Ruederic and Wolter appear to have returned to Kampen and Wolter may be the same as the man that functioned as alderman and councillor between 1505 and 1519. In 1479, Peter van Uterwijc, the son of the castellan of nearby castle Kuinre, also paid off a high fine. ${ }^{118}$ Johan Coipsz, who was an alderman and councillor between 1485 and 1494, was reprimanded by his colleagues on the council for improper conduct with women and 'ander deernen', probably prostitutes, and indiscreet and underhanded talk. They also suspected him of talking about council business outside the council ('dat hie nyet yn rade solde holden dat rait is'). They gave him a stern warning that he would be thrown off the council if his conduct would not improve. ${ }^{119}$ In this case, it may be that Coipsz's status as a magistrate actually exacerbated matters; his behaviour shamed his colleagues. It is possible that his conduct eventually led to Coipsz's departure from the council a year later. Some years earlier, another councillor had also been reprimanded by his colleagues for using improper language in the council and on the street. He was warned to act more honourably in the future, or the council would punish him as they should and as they had previously penalised other council members. ${ }^{120}$

\footnotetext{
${ }^{116}$ Coy, Strangers and Misfits, 58, 60, 68, 74.

${ }^{117}$ Reg, p. 141, 143, 149.

${ }^{118}$ Reg, p. 383.

${ }^{119}$ LC, f. 36r (14 February 1493).

${ }^{120}$ LC, f. 26r (14 August 1488).
} 
So, members of Kampen's elite certainly did not escape justice, and they too might have ended up banished. It is probable that the three members of the Van Uterwijc family were all young men who did not have access to enough money to pay off the large fines set for woundings. In addition, their relatives might have wanted to teach them a lesson by not footing the bill for them, or at least not immediately. As evidence from Italian communes unearthed by Carol Lansing has also suggested, the elite were certainly not averse to breaking the laws they themselves helped to create, and then to prosecute themselves. ${ }^{121}$ In the cases of Ernst Witte and Johan Coipsz, the magistrates may have been genuinely ashamed of their colleagues (as well as concerned that their secrets would be advertised to anyone willing to listen), but they also needed to be seen calling on them to answer for their behaviour. In order to be taken seriously as keepers of a morally pure social order, the magistrates needed to also control their own conduct, and punish those that threatened their status and prestige.

\section{Ceremony and Symbolism}

There is very little evidence concerning any symbolic rituals that accompanied the expulsion of offenders from Kampen. Nothing is mentioned in the by-laws, though this is not unusual in a European context. As Gerd Althoff has argued, secular rituals tended to be flexible; medieval political actors 'varied, mixed, or updated them in keeping with the given situation or even invented new rituals'. ${ }^{122}$ As such, descriptions of rituals did not necessarily find their way into normative texts. In Kampen, some of the only clues are provided by two cases in the Digestum Vetus. In these, warnings were given to the accused (both of them women). Wolbrich was told to leave the town between her trial (17 August 1471) and Christmas Eve of the same year and remain at a distance of at least one mile. If she would not leave during this time, she would be escorted out of town by the executioner banging on a cymbal ('mit eenen becken cloppende'), while she would be made to wear a green wreath on her head. ${ }^{123}$ Her offences had been that she lived apart from her husband, in adultery, had children

${ }^{121}$ Lansing, Passion and Order, 2.

${ }^{122}$ Althoff, 'The variability of rituals', 73. In Scotland the form in which banishments were carried out was not regulated either. Ewan, 'Crossing borders and boundaries', 245.

${ }^{123}$ It is unclear what the green wreath was meant to symbolise. 
annually and was facilitating prostitution. ${ }^{124} \mathrm{~A}$ similar warning was given to Jutte van Bronnepe who had been asked to leave the town immediately for insulting good men and women, generally ungodly living, procuring and fornication with priests, married men and other 'honourable' men. ${ }^{125}$ From this it appears that the women were allowed to leave Kampen of their own accord, Wolbrich even being allowed four months to prepare for her departure. Only if they refused to leave, were they to be subjected to a demeaning ritual. It is questionable then that this ritual was conducted on a regular basis when banishment was the main punishment.

This picture is confirmed when we analyse the other cases in which someone was banished as a primary punishment. In the majority of these cases, the culprits were given a deadline by which they had to leave Kampen, suggesting that they could organise their departure themselves. Usually, this was a defined period within a two-week period. Of 28 banishments in the Liber Causarum, 9 had to leave town within 8 days, 7 within 3 days, 2 each within 1,4 and 14 days and 1 within 5 days. ${ }^{126}$ One person had to leave immediately, one was given 28 days, and in three cases the deadline is not indicated. In some of these entries a date is mentioned by which the exiles had to have left, in others a number of days within which they needed to depart. In the Digestum Vetus the deadline is not mentioned as often as in the Liber Causarum. On a few occasions, people were told to leave 'bij schinender sonne', that is before sunset. ${ }^{127}$ In this context, the four months granted to Wolbrich appear even more generous. Similar spaces of time were found by Maurer for medieval German towns: most commonly until sundown on the same day, 3, 8 or 14 days, and occasionally several weeks. ${ }^{128}$ So there, too, many offenders were able to arrange their own departure. That not everyone left Kampen without any kind of supervision or accompaniment is suggested by a note from 1488 concerning Bette, the 'deerne' of Lambert the 'calckberner' (lime burner), who had returned illegally after having been turned out of

${ }^{124}$ DV, f. 115 r (17 August 1471).

${ }^{125}$ DV, f. 119v (14 December 1471). It should be noted that the men apparently continued to be 'honourable' despite the fornication-the woman was considered to be the seductress.

${ }^{126}$ For example, LC, f. 2 r (1474; within three days), f. 24v (1488; within eight days).

${ }^{127}$ For example, DV, f. 34r (27 September 1459), f. 72r (3 March 1470).

${ }^{128}$ Maurer, 'Erzwungene Ferne', 202. 
the town by a town official ('boeven dat sie myt enen stat diener wt der stadt gewijst was'). ${ }^{129}$

So, instead of being whipped out of the city upon sentencing, as appeared to have been the norm in many cases in sixteenth-century Ulm (though not in Augsburg at the same time) most Kampen exiles were given some time to put their affairs in order, pack their bags and say their goodbyes. ${ }^{130}$ Also, instead of being seen off by a potentially malicious crowd, culprits were able to leave quietly, perhaps escorted only by friends and loved ones. Allowing exiles to leave of their own accord meant that the magistrates surrendered an opportunity to display their power and their commitment maintaining public order. It might be that they had found different ways of making examples of outcasts, for example by publicly announcing their expulsion from Kampen in a symbolic place, but there is no specific evidence of this. In addition, this alternative is unlikely to have been a spectacle like a scourging through the streets which it would have been difficult for the onlookers to forget.

A public spectacle was very occasionally staged, it seems: in 1497 three men were cast out of town ('sijn wt der stat gekloept') as a result of violence. This is the only other case in which the term 'cloppen' was used in the context of a banishment. The men had come to the house of Johan Backer (the baker) and banged on the glass window where his wife was lying-in, five or six days after having given birth. She called her husband, afraid that they were trying to kill her. The men repeatedly demanded that Johan come out of his house, while in the meantime they broke the planks of the window where he normally laid out his bread. ${ }^{131}$ The behaviour of the three men was obviously considered to have been such a serious breach of the peace that they were banished with a public ritual. One of the men was allowed to return in 1505 on payment of 25 gold guilders. It is unclear what the ritual consisted of exactly, but their expulsion was clearly accompanied by noise ('cloppen') which would have alerted Kampen's inhabitants to the proceedings.

In the vast majority of cases there is no mention of any rituals accompanying the banishment. As is clear from the examples presented earlier, it is not that the Kampen magistrates did not use any displays in their punishment practices at all. There were several ways in which punishments could

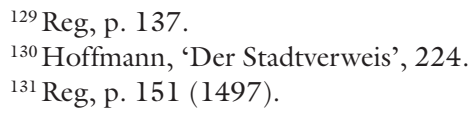


be made to carry an added symbolic weight. Johan Jansz, who took back his confession of theft, had originally been sentenced to wearing a noose as a symbol of having been granted mercy from hanging, possibly while he was being banished, as was already detailed in Chap. 3 . This symbolic gesture is also illustrated in the image accompanying the entry (see Fig. 3.5). ${ }^{132}$ This symbol was, however, related to his crime of theft, for which the punishment was hanging, and not to the banishment. There is no evidence either that any ceremonies took place when an exile was allowed to return to the town, though, of course, the lack of evidence does not rule out that they did. For the town council it was mainly important to note down in its registers who owed it money and who had paid, which warnings were given and to whom and who was banished and on what conditions. These were issues that needed to be recorded and remembered as they needed continued execution and monitoring. ${ }^{133}$ It was much less important to record that a ritual or ceremony had taken place as this did not have any relevance for future dealings with a convict.

Rituals were used elsewhere in Europe when people were banished. In early modern Dundee in Scotland, for example, a female offender was 'scourged about the burgh, with the bellman ringing the hand bell, declaring her offence', after which she was branded on the cheek at the market cross and banished. Others, however, were simply cast out without any rituals. ${ }^{134}$ In medieval London, prostitutes on their third conviction were publicly shorn before being taken to a city gate and cast out of the community. ${ }^{135}$ In medieval Lyon, the condemned were made to follow a set route, including a stop at the pillory. There the culprits were flogged, before being eventually escorted out. Along this route were a number of points representing civic and ecclesiastical power. ${ }^{136}$ Similar routes were followed in medieval Polish towns. ${ }^{137}$ In early modern Ulm, male vagrants were exposed at the pillory and flogged through the streets before being cast out of the city. ${ }^{138}$ Many of the entries in the town's punishment books ('Urgichten') were even accompanied by graphic illustrations showing the

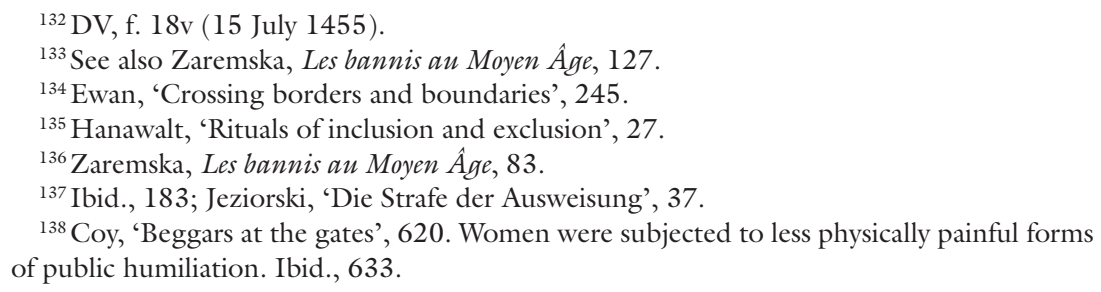


convicted, sometimes with bare upper bodies, being chased by a running executioner with a birch bundle. ${ }^{139}$ In early modern Augsburg, too, corporal punishment and rituals of shaming preceded some banishments. ${ }^{140}$ Of course, in Kampen, too, some of the delinquents were flogged before they were banished, but it is not clear from the sources whether the flogging was considered to be a separate punishment, or that it was a shaming ritual that was attached to the banishment. There is no sign that offenders were flogged through the streets while they were being escorted out. In fact, the entries normally specify that the culprits were flogged at the 'stupe', the pillory. For example, in 1450, Lentien, the son of Peter Claesz, swore an oervede oath because he had been in prison, and he was flogged at the pillory as well as banned from coming within five miles of the town. ${ }^{141}$ Thirteen others were similarly punished between 1447 and 1500 . A few others were branded or mutilated in addition to being banished ensuring their dishonour would be recognised and remembered for the rest of their lives. ${ }^{142}$ Most likely, though, the effect of the combination of flogging and casting out was the same in that the magistrates could showcase their dedication to social order by excluding particular lawbreakers from their midst in a public ritual that would ensure their offences and expulsion would be remembered by as many of the members of the community as possible. ${ }^{143}$ It may be that the magistrates were careful in their decisions concerning who to make an example of. Those who were flogged before an expulsion were culprits who were considered to be dishonourable enough to be kept in custody before their conviction. They were mostly banished for life. The offenders who were allowed to arrange their own departure, on the other hand, were women and men denounced for immoral behaviour. Most of them were expected to return to Kampen in due course. At a time when offenders convicted of immoral acts had perhaps only recently started to be banished, the magistrates may not have been prepared to turn their punishment into a spectacle by flogging them through the streets.

In the western and southern Netherlands, it was common to send offenders on a punitive pilgrimage as an alternative to banishment.

\footnotetext{
${ }^{139}$ Coy, Strangers and Misfits, 130, plus figures on 13, 48 (birch bundle only), 78, 131.

${ }^{140}$ Tyler, 'Refugees and reform', 87.

${ }^{141}$ Reg, p. 2.

${ }^{142}$ For example, Reg, p. 4 (1453), p. 5 (1455), p. 14 (1476, p. 15 (1477).

${ }^{143}$ Coy, 'Beggars at the gates', 620; Coy, Strangers and Misfits, Ch. 5. See also concerning punishment as a process rather than as a single act Geltner, Flogging Others, 25.
} 
Pilgrimages had a symbolic function in that these journeys were meant to purify the lawbreaker as a sinner. Pilgrimages also gave exiles a purpose and as such could be considered more merciful than outright banishment (though a pilgrimage could be equally, if not more dangerous). A pilgrimage also had the added benefit to the town that the exile could not cause any problems on its periphery during their expulsion. ${ }^{144}$ But pilgrimages were not common in the eastern Netherlands (or elsewhere in Europe) and the Kampen court only sentenced a small amount of people to pilgrimages from 1500 onwards, at a time when elsewhere, especially in the western Netherlands in the fifteenth and sixteenth centuries, pilgrimages were slowly being replaced by other penalties. ${ }^{145}$

Overall, then, the Kampen magistrates do not appear to have sought to add symbolic meaning to the act of physically excluding offenders from the town community as a rule, though some offenders were flogged preceding mostly permanent banishments. In order to be able to receive any assistance from the town inhabitants in executing and maintaining banishments, these inhabitants did need to be informed about who was banished and who was allowed to return. It is for the purposes of communication and to stress the complicity of judges and public opinion that rituals and symbolism were especially useful. ${ }^{146}$ Lacking these, there must have been other mechanisms in place. It may be that lists of banished offenders were read out regularly, for example by a town crier or during church services. The town employed a horn blower, who was to blow his horn on all street corners when ordered to do so and when people were taken into custody. ${ }^{147}$ It seems likely that his services were also used to announce who had

${ }^{144}$ Van Herwaarden, Opgelegde bedevaarten, 25, 405; Glaudemans, Om die wrake wille, 185.

${ }^{145}$ Two Kampen examples are known to me from the first years of the sixteenth century: LC, f. 52r (3 December 1500); f. 68v (20 February 1505), the latter offering the offender a choice between banishment and pilgrimage. No research was conducted beyond 1505 . With regard to penal pilgrimages being replaced in the western Netherlands, see Van Herwaarden, Opgelegde bedevaarten, 27. In Dordrecht, for example, the imposing of pilgrimages was significantly reduced in 1400. Van Herwaarden, Opgelegde bedevaarten, 297.

${ }^{146}$ Concerning the transmitting of messages about inclusion and exclusion through rituals, see also Coy, 'Beggars at the gates', 620; Coy, Strangers and Misfits, 26, 81, 120-2; Ewan, 'Crossing borders and boundaries', 245; Gauvard in Zaremska, Les bannis au Moyen Âge, 10; Hawes, 'The urban community', 365-6, 379.

${ }^{147}$ LD, f. 195v; Tamboer and Van Vlisteren, 'Medieval ban horn?', 224 and figure 18. There are also annual payments to the horn blower in the town account, for example, $\mathrm{SR}, \mathrm{f}$. 180r (1490). 
been banished and who had fled from justice. This, combined with the physical expulsion, appears to have generally served the magistrates' objectives of excluding specific offenders from the community and communicating their commitment to maintaining a moral society. ${ }^{148}$ The maintenance of law and social control more generally was communicated through penal practices such as shameful punishments, floggings, mutilations and capital punishments.

\section{An Army of Exiles?}

So, without a purpose like a journey to a saint's shrine, where did the 26-27 people who were banished from the town of Kampen on an annual basis go or what happened to them? From studies of other cities, we know that groups of exiles sometimes hung around just outside the walls or outside the freedom and that it was difficult to monitor and police outcasts returning to the city. In Ulm in the second half of the sixteenth century, for example, stricter laws were issued to act as a deterrent against exiles entering the town, but to little avail. ${ }^{149}$ In medieval Ghent there are indications that exiles caused some unrest just beyond the town bounds. ${ }^{150}$ Similar problems were reported in medieval Dordrecht and Alkmaar. ${ }^{151}$ Throughout Europe, groups of vagrants were considered to be causing trouble and were viewed with increasing suspicion by the authorities and by people more generally. Travellers felt unsafe along certain routes, such as the mountainous and forested regions in Eastern Europe. ${ }^{152}$ Of course, many of these vagrants may have been exiles trying to make a life for themselves without the protection of a static community. Even those who were banished temporarily could be faced with real hardship. They might have been able to enter other cities during daytime, but some towns had

${ }^{148}$ In medieval Fritzlar, too, magistrates made sure banishments were communicated widely. Von Brockdorf, 'Die Strafe des Stadtverweises', 48.

${ }^{149}$ Ulm's policy was mainly aimed at vagrants who, in the economic downturn of this period, flocked to the city. They were increasingly prosecuted and banished, but it proved difficult to prevent them from returning. In addition, 'unruly shanty towns' rose just outside the town walls. Coy, 'Beggars at the gates', 626-8. See also Berents, Misdaad in de Middeleeuwen, 49-50; Berents, Het werk van de vos, 80. Coy, Strangers and Misfits, 31-56.

${ }^{150}$ Van Eetveld, 'Vrouwencriminaliteit', 10. Seeing that Ghent banishments were apparently valid for the whole of Flanders, this suggests that monitoring was a real issue.

${ }^{151}$ Glaudemans, Om die wrake wille, 199.

${ }^{152}$ Glaudemans, Om die wrake wille, 199, 204, 206; Zaremska, Les bannis au Moyen Âge, 101 . 
by-laws against 'foreign' exiles staying overnight. They had to leave town before sundown. ${ }^{153}$ A captured exile in Zeeland reported in 1502 that he had slept mostly in fields and meadows for the past two years, and only very rarely in houses and on beds. ${ }^{154}$ Others might have been able to stay with friends or family. For some, a banishment might just have been another stage in their migratory life. Zaremska has asked to what extent exile was an actual punishment when so many in urban society came from elsewhere and a life of mobility was fairly normal. In Avignon, in the second quarter of the fourteenth century, for example, about three-quarters of the population consisted of newcomers. ${ }^{155}$ How successful an individual was in making a new life for themselves after a banishment depended on different factors, such as character, background and age, but also on the economic viability of the region they were living in. In general, though, it is difficult to get a clear picture about the activities and whereabouts of exiles.

In Kampen there is some evidence that people returned to town before their banishment was up. First of all, there are the by-laws which concern returned exiles which were discussed in Chap. 2: in 1334 it was laid down that people who fled or were exiled because of an unpaid fine and were caught within the town or freedom after their banishment should be fined $80 \mathrm{lb}$. For those who had been ousted from the community for debts it was half the fine. Anyone assisting exiles by offering them a place to stay was meted out the same penalty. ${ }^{156}$ In the second half of the fifteenth century, there were obviously some problems with returning exiles, as in 1479 when the town offered anyone who arrested an outcast, or was instrumental in their arrest, half the fine, that is to say $40 \mathrm{lb}$. for catching anyone due a fine. ${ }^{157}$ For exiles who were 'only' flogged or otherwise punished corporally on their return, the town would pay the informer $10 \mathrm{lb}$. The oath of the bridgemaster, recorded in 1466, also included the promise that he would inform the burgomasters of any exiles crossing the bridge in either direction. ${ }^{158}$

\footnotetext{
${ }^{153}$ Berents, Het werk van de vos, 80 .

${ }^{154}$ Glaudemans, Om die wrake wille, 197.

${ }^{155}$ Zaremska, Les bannis au Moyen Age, 84, 171.

${ }^{156} \mathrm{~GB}$, f. $42 \mathrm{v}$. In Valenciennes, people could be banished themselves for helping others. Huart, 'Maintenir la paix', 15.

${ }^{157} \mathrm{DN}, \mathrm{f} .3 \operatorname{lr}(1479)$. The promise of half the fine was also included in some other by-laws.

${ }^{158} \mathrm{DN}, \mathrm{f}$. 12r. The bridge across the IJssel was built in 1448 .
} 
The register of banishments also includes some evidence that on occasion exiles returned to the town before their fines were paid. Thirty-three entries, all dated between 1451 and 1492, have annotations concerning additional fines for unauthorised returns to Kampen. In accordance with the by-laws, $80 \mathrm{lb}$. was added to their existing fines with the exception of Diric Gijsbertsz who had been banished for debt and, again following the regulations, was charged with an extra $40 \mathrm{lb} .{ }^{159}$ Five of the exiles had been spotted twice and as a result had $160 \mathrm{lb}$. added to their fine. The bridgemasters caught at least some of the offenders: on three occasions (all after the above mentioned 1466 by-law) it is noted that the outcasts were seen (or caught) on the bridge. ${ }^{160}$

It is difficult to say whether these 33 offenders were just the tip of the iceberg. Without a police force, it would have been difficult to monitor the return of any exiles, especially outside the gates in the freedom. The bridgemaster and the watchmen by the gates (who are also said to have caught offenders on three occasions $)^{161}$ would have kept an eye out, as did the aldermen who apparently spotted an exile in the town freedom in 1488. ${ }^{162}$ Obviously, though, it was possible to enter the town unobserved, as most offenders were caught inside the town walls. Some were even caught in very public spaces, such as St Mary's church, the town cellar and one of the town's taverns. ${ }^{163}$ It is likely, then, that many turned a blind eye when they spotted an exile. The 1479 by-law suggests that the magistrates realised that more exiles were returning than they would be able to catch and that they needed help from inhabitants in policing returning outcasts. How they came to this conclusion remains the question (perhaps they noticed that exiles' goods were secretly removed), ${ }^{164}$ but it is unlikely that they would have issued a by-law if less than one exile returned to the city unauthorised every year. This also suggests that the magistrates had trouble convincing the inhabitants to cooperate in catching these men and women. It was important, then, to be able to depend on the men guarding the gates. In seventeenth-century Augsburg, exiles were taken to all

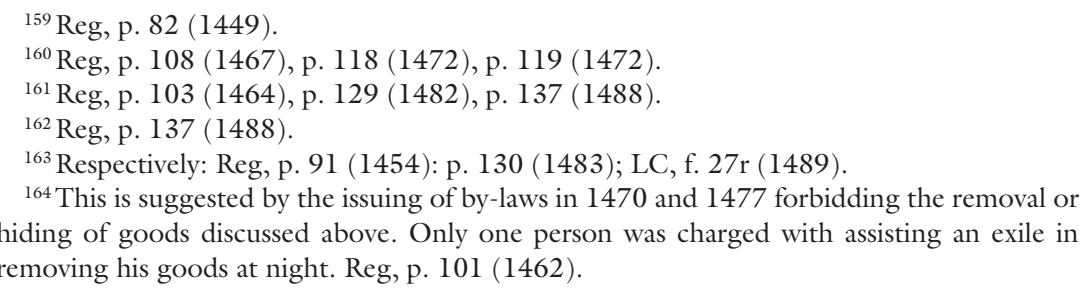


the gates so the gatekeepers could take a good look at them. ${ }^{165}$ This may have been a common measure in medieval and early modern Europe and suggests that exiles returning was a problem that existed everywhere.

The fact that people took the risk of an additional $80 \mathrm{lb}$. fine also suggests that the chances of being caught were low and that they were likely being supported (or at least ignored) by many within the town. In some cases, though, people seemed especially unlucky. Jan Arntsz, for example, was banished for a mere $2 \mathrm{lb}$. in 1466, but saw $80 \mathrm{lb}$. added to this when he was spotted in Kampen. ${ }^{166}$ The same happened to Tyman Luttike in 1462, on top of the $9 \mathrm{lb}$. he owed the town. ${ }^{167}$ Despite this, Luttike subsequently managed to repay his debt and was allowed to return to join the town community. But one can only imagine that an $89 \mathrm{lb}$. fine would have taken a long time to settle for someone who had initially been unable to pay $9 \mathrm{lb}$. Johan Matthijsz, on the other hand, was already due to pay the enormous sum of $460 \mathrm{lb}$. in 1453 when he was caught inside the town freedom. His high fine was the result of a night of violence: he had gone out one night and had attacked a number of individuals, including a blind man who had the snares of his lute broken before he ended up with a bloody nose and mouth. Another $80 \mathrm{lb}$. was added when he returned to town. He too apparently managed to pay off his debt, as his entry has been crossed out (more regarding this in Chap. 5). ${ }^{168}$ That a continued watch was out for people who had been registered as banished, becomes clear from the case of Johan Heymansz who was cast out of the town in 1459 for a fine for pulling the cape or coat off a brother of St Brigit. Heymansz returned four years later, in 1463, was recognised, and also had $80 \mathrm{lb}$. added to his fine. ${ }^{169} \mathrm{~A}$ case which appears even more extraordinary is that of Evert Koster who was banished in 1480 for failing to pay a fine for the use of an illegal weapon. This entry states that he was caught in Kampen on two occasions: at Easter in the year 1500 and at Visitationis (2 July) in 1502. ${ }^{170}$ The reason that he was caught, the second time at least, was that his wife had filed a complaint because he had broken open her door with

\footnotetext{
${ }^{165}$ Illegal returns were registered systematically in Augsburg from 1600. From this registration, it is clear that some exiles returned repeatedly. One individual was even caught 22 times. Hoffmann, 'Der Stadtverweis', 218, 221.

${ }^{166}$ Reg, p. 107 (1466).

${ }^{167}$ Reg, p. 101 (1462). The entry was crossed out.

${ }^{168}$ Reg, p. 86 (1453). The entry was crossed out.

${ }^{169}$ Reg, p. 97 (1459 (and 1463)).

${ }^{170}$ Reg, p. 128.
} 
an axe which he had brought along. It appears, then, that Evert had never paid his fine and was still banished 22 years after he was cast out. In the meantime, his wife had remained in Kampen and had obviously been able to manage without him. It may well be that she only denounced him because he threatened her.

Besides the by-laws and notes on added fines in the banishment register, there is no evidence that the magistrates were concerned about any 'armies' of exiles on the borders of their town freedom. ${ }^{171}$ Schuster, in his study of Konstanz, has suggested that outcasts were only able to keep up their social connections within the town if they were exiled for no more than a year or at a distance of a few miles. For this reason, offenders sentenced to banishments from Konstanz for longer than one year in particular tried to get these sentences converted to fines. Those who decided to leave the town after all tried to stay as close as possible, so as to be able to keep in touch with relatives and friends or even keep an eye on business where relevant. ${ }^{172}$ But such exiles were not necessarily the ones the town magistrates would be concerned about. It was poor, unemployed folk without any connections that town councils in the middle ages and early modern period sought to keep out of their walled communities, such as the people flocking to the city of Ulm mentioned above. They were subsequently cast out when they became a burden and settled in the shanty towns around the walls. ${ }^{173}$ Of course, such groups mainly became a burden when a town was in economic decline; growing cities like Amsterdam even welcomed those banished from elsewhere as long as they obeyed the law. ${ }^{174}$

It appears that the economic situation in Kampen was not as desperate as that in Ulm, at least not in the fifteenth century. It was not until the early sixteenth century that wars waged in the surrounding countryside might have led to an increase of fugitives in Kampen. On the other hand, there does appear to have been an increase in by-laws in the last quarter of

\footnotetext{
${ }^{171}$ Berents, Misdaad in de Middeleeuwen, 49, does mention an 'army of exiles' outside the city of Utrecht. According to him, many of the robbers sentenced in Utrecht were exiled inhabitants of Utrecht. See also Berents, Het werk van de vos, 80, where he mentions that some towns did not allow exiles from other places to remain in the city after dark (which suggests it was known who they were), forcing exiles into a life of vagabondage and robbery. Unfortunately, he does not supply any references for this claim.

${ }^{172}$ Schuster, Stadt vor Gericht, 248-9.

${ }^{173}$ Coy, 'Beggars at the gates', 620, 628.

${ }^{174}$ Boomgaard, Misdaad en Straf in Amsterdam, 156.
} 
the century on the presence of undesirables, or basically anyone 'foreign', in the town, especially at night, but this may have been the result of concerns of morality more than economics. None of these laws were, however, specifically aimed at solving any problems with outcasts just beyond the town. ${ }^{175}$ Perhaps the numbers being banished from Kampen were not large enough at this time to create such problems. It may also be that exiles had sufficient other places to go to in the vicinity, such as, among others, Zwolle, Elburg, Hattem and Hasselt.

As has already been pointed out, banishment perhaps created more problems than it was meant to solve. An expulsion from an urban community could be the start of an itinerant life of crime. When people lost their livelihoods, they sometimes did not have any other choice than to scrape by through stealing and robbing. If towns did not allow exiles from other places into their communities, or severely restricted the possibilities of 'strangers', then their options were limited. This is, of course, based on the assumption that magistrates knew that these people had been banished from elsewhere. It is unlikely that town councils were informed about every single person that had been cast out from other towns, but there is some evidence that there was information exchange between towns about exiles and lawbreakers. ${ }^{176}$ Henric die Cruijsser, who was executed in Kampen in 1483 for a number of violent crimes and theft, confessed to having been banished from Utrecht. ${ }^{177}$ Elsewhere in Europe, neighbouring towns appear to have set up various arrangements to deal with the

${ }^{175}$ In 1478,1493 and 1498 by-laws were issued regulating the stay of strangers in inns (DN, f. 29r (1478); f. 47r (1493); f. 50v (1498)). In 1483 it was laid down that strangers could not walk the streets after nine o'clock (DN f. $34 \mathrm{r}(1483)$ ). A year later the use of disguises out in the open was proscribed (DN, f. 34r (1484)). In 1496 infamous persons, common women and others like them were disallowed buying property in the city (DN, f. $49 \mathrm{v}$ (1496)). In 1461, 1467 and 1492 beggars were banned from begging in churches, though they were allowed to beg in churchyards and elsewhere (DN, f. 9r (1461); f. 15v (1467); f. $45 \mathrm{v}(1492))$. Overall, however, regulations in Kampen against begging were surprisingly lax. See Brand and Frankot, 'Das Kampener Stadtbuch', 48-9. In Ulm, the magistrates began 'to enforce vagrancy statutes more energetically' only in the second half of the sixteenth century. Coy, 'Beggars at the gates', 626.

${ }^{176}$ The detailed lists of crimes committed (and confessed to) by the offenders who were mutilated or executed, for example, suggest towns were exchanging information on these matters. The 'limping man' who was flogged and banished for crimes committed in Kampen in 1455 was known to have committed manslaughter in Emmerich before. DV, f. 16v (24 April 1455). See also the case of Hendrik Hoeymaker in Chap. 5.

${ }^{177}$ Reg, p. 226 (17 March 1483). 
problem of exiles. In 1241, Hamburg and Lübeck agreed to exchange information about fugitives and to respect each other's sentences. This agreement was later followed by wider Hanseatic collaboration. Registers concerning banishments in various towns, such as Stralsund, include entries concerning crimes from other places. ${ }^{178}$ Thirteenth-century Valenciennes and Saint-Quentin were also communicating about exiles, aiming to make banishments effective for a large area. ${ }^{179}$ In the Polish kingdom and Silesia, confederations of towns existed in the middle ages, and banishments were valid in all the towns of such a confederation. Presumably, the towns corresponded with each other about who was exiled. ${ }^{180}$ In Southern Germany and Switzerland too, towns cooperated to keep exiles out of a larger area, so they were prevented from causing problems for neighbours. ${ }^{181}$ In Göttingen, a different solution to problems with expulsed individuals was sought: there the magistrates increasingly imposed different punishments from around 1420. This also prevented any negative consequences on the economy due to the absence of productive members of society. ${ }^{182}$

To conclude, it is clear that the Kampen town council in the second half of the fifteenth century increasingly preferred to protect the community from the potential dangers of allowing strangers into its midst (unless, of course, these strangers came to trade goods). At the same time, it excluded more and more people, especially women, from the town community for deviant behaviour. With these actions they were most likely responding to an increasing demand from certain groups within society who denounced their neighbours for morally offensive and disruptive behaviour, and expected the magistrates to deal with the culprits. In the last quarter of the fifteenth century, there was a clear increase in the punishment of women for such acts. At the same time, though, the magistrates do not yet appear to have used rituals to accompany the physical act of exclusion in order to communicate their commitment to maintaining a well-ordered and morally pure town. Instead, banishments were perhaps only announced publicly in a number of arenas. The general public, in the meantime, do not appear to have been particularly active in capturing exiles who had returned

\footnotetext{
${ }^{178}$ Zaremska, Les bannis au Moyen Âge, 90.

${ }^{179}$ Huart, 'Maintenir la paix', 7-8.

${ }^{180}$ Zaremska, Les bannis au Moyen Âge, 162-3.

${ }^{181}$ Maurer, 'Erzwungene Ferne', 212; Marchal, "“Von der Stadt”, 253.

${ }^{182}$ Boockmann, Urfehde und ewige Gefangenschaft, 45-8.
} 
illegally. It may be that most people were eager to denounce their neighbours when their behaviour annoyed or offended them personally. ${ }^{183}$ However, when an exiled individual returned to town and did not bother them specifically, they might have been happy to turn a blind eye. That the magistrates could also show mercy to those that were willing to mend their ways (and arrange to pay their fines) shall become clear in the following chapter.

${ }^{183}$ See also Smail, The Consumption of Justice, 18.

Open Access This chapter is licensed under the terms of the Creative Commons Attribution 4.0 International License (http://creativecommons.org/licenses/ by $/ 4.0 /$ ), which permits use, sharing, adaptation, distribution and reproduction in any medium or format, as long as you give appropriate credit to the original author(s) and the source, provide a link to the Creative Commons licence and indicate if changes were made.

The images or other third party material in this chapter are included in the chapter's Creative Commons licence, unless indicated otherwise in a credit line to the material. If material is not included in the chapter's Creative Commons licence and your intended use is not permitted by statutory regulation or exceeds the permitted use, you will need to obtain permission directly from the copyright holder.

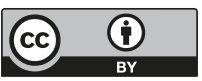

